\title{
UOSTAMIESČIO VIZUALINIO İVIZDŽIO PLĖTROS GALIMYBĖS IR PROBLEMOS: AUKŠTYBINIŲ PASTATŲ IŠDĖSTYMO SPECIALIOJO PLANO RENGIMAS - SPRENDINIŲ KONKRETIZAVIMAS IR PASEKMIŲ VERTINIMAS
}

\author{
Inesa Alistratovaitè \\ Urbanistikos katedra, Vilniaus Gedimino technikos universitetas, \\ Pylimo g. 26/ Trakug. 1, LT-01132 Vilnius, Lietuva, el. paštas: inesa.al@gmail.com \\ Itteikta 20090428
}

\begin{abstract}
Santrauka. Straipsnis skirtas aukštybinès statybos plètros klausimui ir su tuo susijusioms šiandieninèms miesto plètros vizijos formavimo problemoms Lietuvoje. Nagrinėjamos Klaipėdos miesto vizualinio įvaizdžio plètros galimybès ir problemos rengiant Klaipėdos miesto aukštybinių pastatų išdèstymo specialųji planą (SP). Šio plano metodikai aptarti yra skirti du autorés straipsniai. Pirmajame jau aptarti du plano rengimo etapai - esama Klaipèdos miesto būklè ir aukštybinių pastatų išdejstymo koncepcijos paieška. Šiame antrajame aptariami kiti du plano rengimo etapai - tai sprendinių konkretizavimas ir jų pasekmių įvairiais aspektais įvertinimas. Pateiktas miesto teritorijų, atitinkančių kompozicinès plètros idẻją, įvertinimas šiais aspektais: miesto struktūrinių elementų užstatymo morfostruktūros kitimo prognozé, miesto struktūrinių elementų užstatymo perspektyvinio foninio aukštingumo kitimo prognozė ir aukštybinès statybos plètojimo miesto urbanistineje struktūroje konkretizavimas. Pateikti aukštybinių pastatų išdèstymo specialiojo plano rezultatai. Aptartas aukštybinių pastatų išdėstymo sprendinių pasekmių vertinimas miesto vizualiniam ịvaizdžiui, stebint iš nustatytų masinès apžvalgos taškų, bei poveikis bendram miesto silueto ir panoramų pokyčiui.
\end{abstract}

Reikšminiai žodžiai: Klaipeda, specialusis planas, vizualinio įvaizdžio plètra, miesto morfostruktūra, aukštybiniai pastatai, sprendinių konkretizavimas, vizualinis identitetas.

\section{Ivadas}

Atkūrus nepriklausomybę, privatus kapitalas, siekdamas komercinès ir ekonominès sèkmès, ne be globalizacinių procesų skatinimo èmé intensyviai veržtis ị centrines dalis. Tai kiek pristabdè 1997-1998 m. Rusiją ištikusi krizè, kuri turèjo didelès įtakos ir Lietuvai 1998-2000 m. (dar vis tebesistengiančiai ištrūkti iš taip ilgai trukusio valstybinio sąstingio). Investicinis kapitalas ị nekilnojamąji turtą dar nekèlé didelių diskusijų apie jo kontrolę, nes didelių pokyčių ar jų pasekmių nesimate. Tuo metu gana sąmoningai skambejjo didmiesčių merų ketinimai suteikti didesnę laisvę investicijoms - kur tik investuotojai pageidautu, ten ir leisti planuoti aukštuminius pastatus. Greitai šis leidimas buvo suvoktas kaip destrukcinis kirtis miestu savasties ir identiteto pagrindui, jo išskirtinumui ir unikalumui ne tik gamtinès ir urbanistinès morfostruktūros požiūriu, bet ir mūsų savimonès atžvilgiu.

Todèl nenuostabu, kad panašūs pareiškimai, o vèliau ir vienas kitas investicinis proveržis išprovokavo miestų struktūros sergètojus parengti aukštybinių pastatų išdèstymo specialiųjų planų rengimo taisykles $2004 \mathrm{~m}$. (Aukštybinių ... 2004), kuriomis vadovautasi ir rengiant Lietuvos uostamiesčio aukštybinių pastatų išdèstymo specialujji planą.

Šiame straipsnyje toliau nagrinëjama autorès anksčiau gvildenta tema (Alistratovaitè 2008) apie Klaipèdos miesto aukštybinès statybos pletros galimybes ir su tuo susijusios problemos. Pirmajame autorès straipsnyje, skirtame Klaipėdos aukštybinių pastatų išdèstymo specialiojo plano rengimui aprašyti, išdėstyti tikslai, uždaviniai ir pati darbo metodika. Jame buvo aprašyti ir du plano rengimo etapai - esamas Klaipédos miesto būklès tyrimas, apimantis 7 aspektus, ir aukštybinių pastatų išdèstymo koncepcijos paieškos skirtingais 
miesto lygmenims. Kadangi šis straipsnis yra tęstinis, jame toliau analizuojami likę du Klaipèdos aukštybinių pastatų išdèstymo specialiojo plano rengimo etapai tai sprendinių konkretizavimas ir jų pasekmių įvairiais aspektais vertinimas, kuriais remiantis pateikiamos uostamiesčio vizualinio įvaizdžio formavimo galimybès ir problemos.

Šio straipsnio tikslas - atskleisti Klaipedos miesto morfostruktūros realias galimybes ir sąlygas realizuoti parinktą perspektyvinį miesto kompozicinio karkaso modelį, taikomą aukštybinei statybai plètoti. Remiantis miesto teritorijomis, atitinkančiomis kompozicinès plètros idejją, išdèstyta:

- miesto struktūrinių elementų užstatymo morfostruktūros kitimo prognozé;

- miesto struktūrinių elementų užstatymo perspektyvinio foninio aukštingumo kitimo prognoze;

- aukštybinès statybos plètojimo miesto urbanistineje struktūroje konkretūs atvejai.

Pateikti aukštybinių pastatų išdèstymo specialiojo plano rezultatai ir pasekmių vertinimas miesto vizualiniam ịvaizdžiui, stebint iš nustatytų masinès apžvalgos taškų, bei poveikis bendram miesto silueto ir panoramų pokyčiui.

Strateginių pasekmių aplinkai vertinimas (poveikio socialinei aplinkai, ekologinių sąlygų kitimo dèl didejjančio autotransporto srautų, poveikio ekonominei aplinkai didejant užstatymo intensyvumui) buvo atliekamas kitų kompetentingų specialistų, kurių išsakyti pastebejjimai neprieštaravo specialiojo plano derinimo eigai ir straipsnyje išsamiau nepateikiami.

\section{Aukštybinių pastatų išdèstymo nustatymas (specialiojo plano konkretizavimo dalis)}

Sprendinių detalizavimo etape tikslinamos teritoriju ribos, aukštybinių pastatų statybos vietos, kurios buvo numatytos koncepcijoje ${ }^{1}$ (1 pav.). Joje siekta kokybiškai plètoti miestą (socialiniu, ekonominiu, kultūriniu pagrindu), o ị paveldo teritorijas žvelgta ne kaip ị statišką ir izoliuotą vienetą, bet kaip ị integralų miesto respektuojamą morfostruktūros elementą, kuris yra visos miesto kompozicijos kulminacija. Todèl sprendinius lèmé pagrindinis metodinis principas - glaudus miesto struktūrinių zonų sąlytis su jų miestovaizdžių mozaika.

\footnotetext{
${ }^{1}$ Pastebejimas - žurnale Urbanistika ir architektūra, 2008, 32(2), p. 81,10 pav. padaryta eiliškumo klaida: perspektyvinis miesto kompozicinio karkaso modelis, pažymètas Nr. II, turi būti sukeistas vietomis su Nr. III. Eiliškumas tekste aprašytas teisinga seka.
}

Aukštybinių pastatų išdèstymo nustatymas skirstomas ị dvi dalis:

- miesto teritorijų, atitinkančių kompozicinès plètros idèją, ịvertinimas galimo užstatymo aukštybiniais pastatais požiūriu;

- Klaipėdos miesto aukštybinių pastatų išdèstymo specialiojo plano rezultatų požiūriu.

Atsižvelgiant į tai, kad miestas yra nevienalytė struktūra tiek funkciniu, tiek morfostruktūriniu, tiek estetiniu požiūriu, visa miesto teritorija struktūrizuota pagal kompozicinius kriterijus (morfostruktūros vientisumą ir jos fizines ribas). Šis principas laikomas kiekvieno miesto urbanistinès struktūros identiteto pagrindu, nes atskirų miestovaizdžių stiprinimas yra sąmoningas skirtingų (senesnių ir modernesnių) struktūrų teritorinis atskyrimas. Bendrąja prasme Lietuvos miestai tarsi skirtingų laikmečių dèlionès, kuriomis bandoma užpildyti ankstesnių laikotarpių spragas ar morfostruktūrinius nuostolius. Todèl daugelị miestų galima traktuoti kaip atskirų susiformavusių teritorinių vienetų junginius. Tą patvirtinto ir Klaipèdos miesto atvejis-teritorija traktuojama kaip struktūrinių zonų mozaika, bet ne kaip vientisas teritorinis administracinis darinys (2 pav.). Respektuojami raiškūs Klaipèdos miesto struktūros elementai, kiekvienam išjų nustatant plètros galimybes ir poreikị. Jie išskirti vadovaujantis fizinèmis ribomis ir egzistuojančiu vientisu morfostruktūros charakteriu: infrastruktūros elementais intensyvesnemis transporto arterijomis (šiuo atveju Paryžiaus Komunos g., Mokyklos g., Baltijos pr., geležinkelio linija ir kt.), gamtiniais elementais, jų gausa ir vyravimu -želdynais (Klaipèdos miško riba) ir vandens telkiniais (Kuršių marios, Minijos upè). Identifikuotos šios Klaipédos miesto zonos ir jų dalys:

- miesto centrine dalis (MCD);

- šiaurinè miesto zona, jos dalys - Klaipėdos miškas (ŠMD.Misk) ir teritorija tarp Klaipedos miško ir Minijos upès iki geležinkelio linijos (ŠMD1);

- rytiné miesto zona, jos dalys - nuo Minijos upés (RMD1) ir geležinkelio linijos (RMD2) i r rytus, jų skiriamoji riba yra Baltijos pr.;

- pietiné miesto zona, jos dalys - ribojamos geležinkelio linijos ir Kuršiu marių, o skiriamos Baltijos pr. (PMD1, PMD2);

- vakarinè miesto zona, jos dalys - tai pajūrio zona (VMD.Pjr) ir Smiltynè (VMD.Sml) - fiziškai atskiros miesto dalys.

Struktūrizuojant Klaipedos miestą pagal kompozicinius kriterijus ryškejja teritorijų hierarchija, stiprinanti uostamiesčio vizualinị ịvaizdị: kiekvienai zonai 


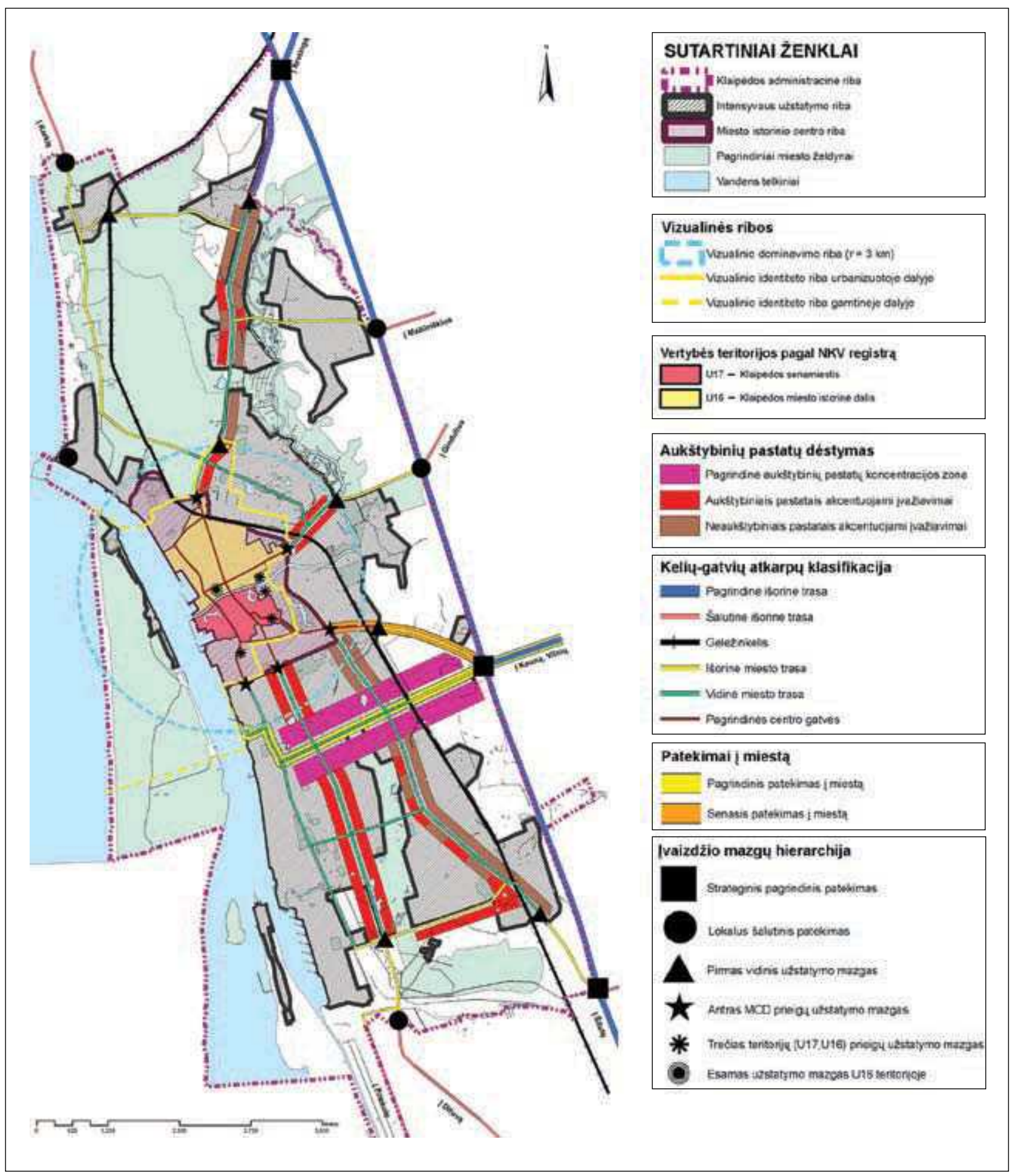

1 pav. Perspektyvinis miesto kompozicinio karkaso modelis, taikomas aukštybinei statybai plètoti

Fig. 1. Perspective model of the city compositional framework for development of high-rise building 


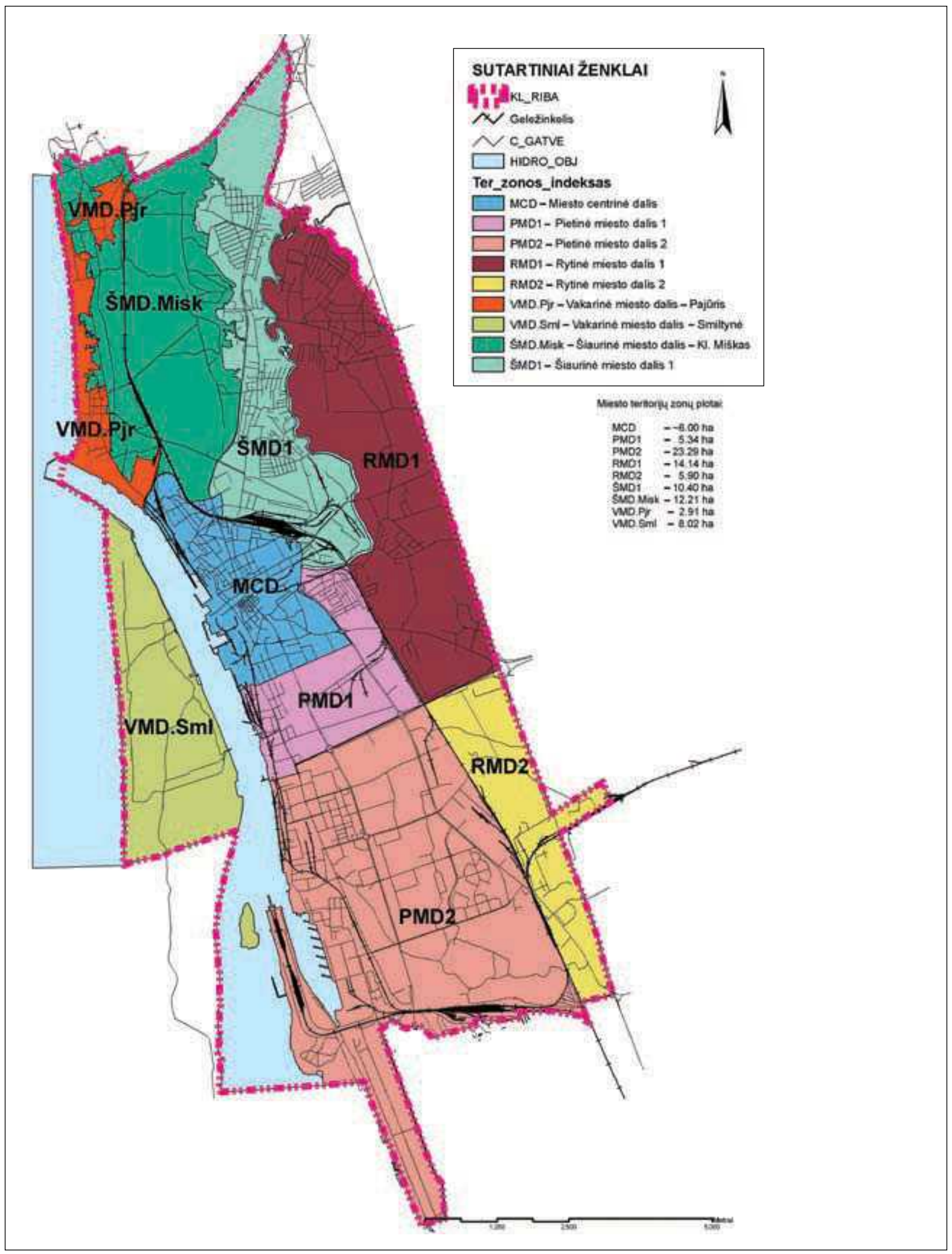

2 pav. Klaipèdos miesto struktūrizavimas pagal kompozicinius kriterijus

Fig. 2. Structurization of Klaipèda city under compositional criteria 
būdingas individualus charakteris, kai kuriose jų taikant griežtą projektavimo kontrolę.

Atskirų miesto zonų hierarchizavimas jų plètrai keliant individualius reikalavimus egzistuoja daugelyje šalių, vykdant ilgametę vertybinių teritorijų politiką. Iš Vakarų Europos ryškiausiai atskiromis miestovaizdžių teritorijomis išsiskiria bei vadovaujasi šioms teritorijoms nustaty ta reglamentų sistema ne tik skirtingi miestai, bet ir jų šalys:

- Barselonos miestas Ispanijoje garséja įsimintina planavimo sistema - tai kadaise buvusios priemiesčio teritorijos (jau tapusios centrine miesto dalimi), kurių kvartalai suplanuoti Šerda (Cerda) principu ${ }^{2}$. Šioje dalyje kaip kitose dalyse užstatymo principai griežtai reglamentuojami išsaugant konkrečios zonos charakterí, visų pirma vadovaujantis Šerda nustatytu teritorijos užstatymo tipu su galimybe keisti jo rodiklius, nesugriaunant bendros idejos ir išsaugant foninị aukštị;

- Italijos miestai - didieji - Roma, Florencija; mažesnieji - Turinas, Siena, Piza, Luka, Perudžija, Bolonija ir kt. - turi mažiausiai pakitusius per industrinį laikotarpị istorinius centrus. Juose stengiamasi išlaikyti aiškius miestovaizdžio tipus. Griežta statybos politika retai leidžia prasmukti abejotinos kokybės objektui. Dažnai taikomas tūrio tankio rodiklis, kuris priklauso nuo sklypo dydžio bei teritorijos padèties mieste. Jo išraiška yra pastato kubinių metrų kiekis vienam sklypo kvadratiniam metrui. Lietuvoje šis rodiklis taikomas pramonès ir infrastruktūros teritorijose, bet jị būtų tikslinga taikyti ir kitos funkcijos teritorijoms, nes užtikrintų didesnę kontrolę ir prognozuotų tikslesnį rezultatą;

- Vokietijoje jau kelintą dešimtmetị egzistuoja itin griežtos normos, kurios padeda formuoti teritorijas atskirais miestovaizdžiais (remiantis kai kuriomis taisyklemis buvo rengta: Vilniaus Naujamiesčio raidos programa, užstatytų Vilniaus teritorijų tankinimo metodika ir kt. (Vilniaus ... 2000, 2001; Pakalnis 2000));

- Prancūzijoje, ypač pietų, mažesnių miestų miestovaizdis stiprinimas planavimą reglamentuojančiomis priemonemis. Taip pat reikètų paminèti Paryžiaus atveji, čia istorinio centro vertybe buvo pripažintas užstatymo foninis aukštis bei jo stogų

\footnotetext{
2 Ispanų miestų planuotojas (katalonas) Ildefons Cerda y Sunyer $1859 \mathrm{~m}$. pasiülè labai savitą plètros planą Barselonos prieigoms (Barcelona's Eixample) už senamiesčio gynybinès sienos ribų. $1860 \mathrm{~m}$. vykusiame konkurse šis projektas buvo išrinktas geriausiu ir Cerda suteiktas šalies vyriausybès pasitikejjimas ji realizuoti (Ward 2002).
}

mozaika, todèl $1960 \mathrm{~m}$. aukštybinių pastatų statybos (tuo metu jau atkeliavusios iš Amerikos) buvo uždraustos istoriniame miesto centre ir nukreiptos ị konversines zonas už miesto centrinès dalies (Eliziejaus laukų ašyje) dabartiniame La Defense rajone. Šis žingsnis užtikrino miestovaizdžių išsaugojimą ateities kartoms (3 pav.);

- priešingai negu Paryžiuje, Londone istorinès miesto dalies miestovaizdis dar prieškario industrializacijos metais ir kiek vèliau buvo keičiamas aukštesnių nei esamas foninis aukštis pastatų statyba, tai lèmé disonansiškumą aukštingumo požiūriu. Kiek vèliau šis miestovaizdis buvo tarsi tobulinamas žymių architektų darbais, nors iš principo industrinį palikimą skandino naujos kokybės statyba. Ypač po 2000 m., kai miesto meru išrinktas Ken Livingstone, kuris naudodamasis politika protegavo globalios sostinès vaidmeni Londonui, skatindamas ir remdamas didejjantį užstatymo intensyvumą visame mieste (The Endless City 2007) (3 pav.);

- Rusijos miestuose netaikomos miestovaizdžiu reglamentavimo programos (Маклакова 2006), tačiau jų savitumui išsaugoti didelę reikšmę turèjo dar 1985 m. mokslininkès L. Kožajevos paskelbtas straipsnis apie Maskvos morfotipus (Кожаева 1987). Jame išdèstyta užstatymo tipų samprata buvo tuometinès stiprios Rusijos urbanistikos teorijos rezultatas, deja, iteisintas tik po $22 \mathrm{~m}$. šios šalies miestų planavimo įstatymuose (О внесении ... 2005), tai ateityje turètų veikti pačią miestovaizdžių struktūrą, jų tapatumą mieste.

Remiantis šiais pavyzdžiais galima daryti prielaidą, kad miestovaizdžių charakterius išskirti, jų identitetą stiprinti galima dviem būdais: pirmas - taikant savitą (tvarkant esamą arba planuojant naują teritoriją) planavimo, kuriuo apsupamas vieno (ankstesnio) laikotarpio miestovaizdis, metodą ir taip jis išsaugomas (Barselonos atvejis), arba kuriant naujas miestovaizdžių renovacijos programas, pagal kurias griežtai reglamentuojama plètra, remiantis konkrečios struktūros formavimo principais, taip po truputị skiriami ir tobulinami miestovaizdžių charakteriai. Klaipèdos atvejui pasirinktas pastarasis būdas, kai respektuojami unikalūs vertingiausi tiek miesto urbanistinio karkaso, tiek susiformavusių miestovaizdžių, tiek gamtinès morfostruktūros elementai (vandens telkiniai; želdynų masyvai, fragmentai; senamiesčio ir naujamiesčio teritorijos; architektūriniai ir urbanistiniai ansambliai, jų liekanos; pavieniai statiniai), konkrečiai nusakant jų plètros galimybes. 


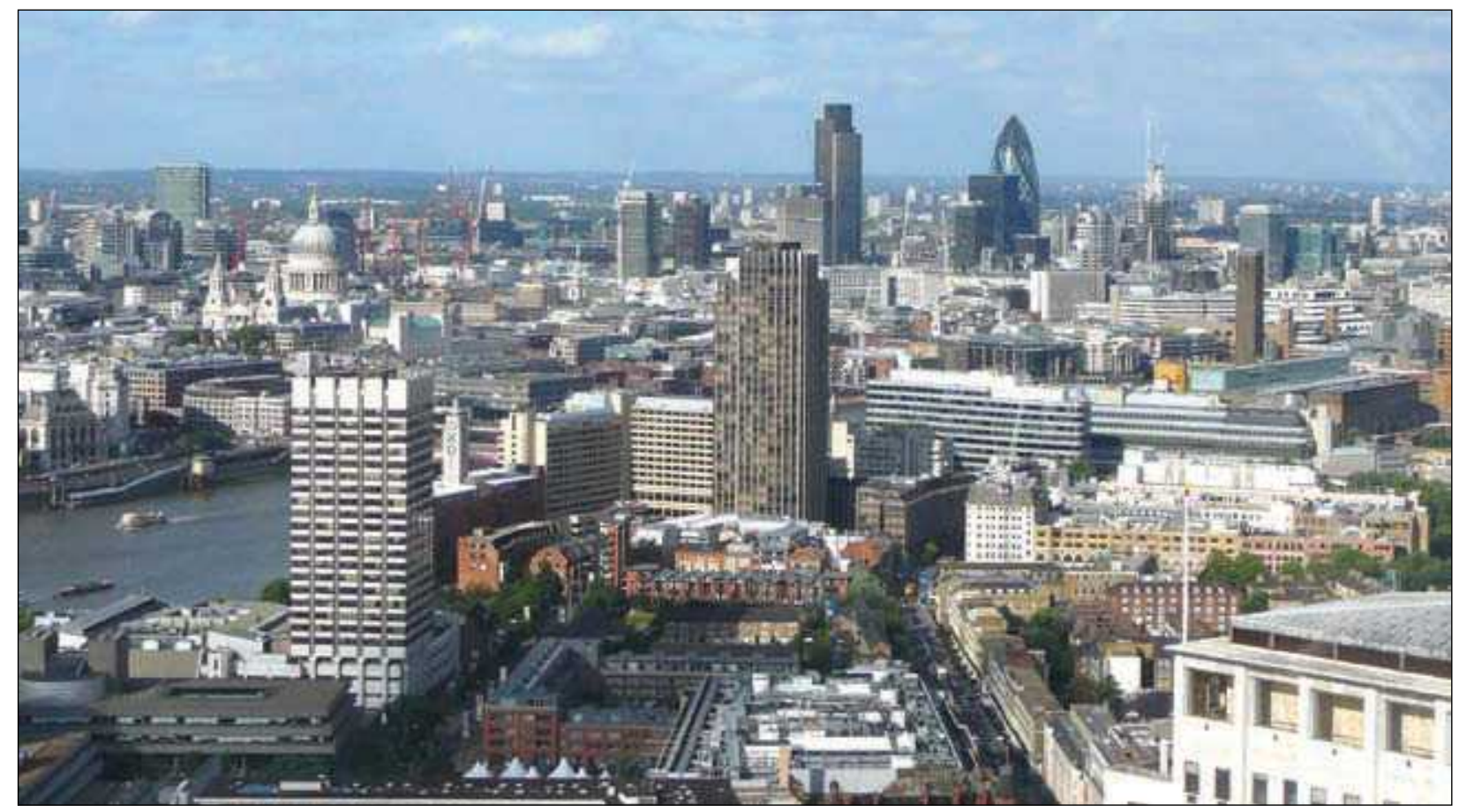

A

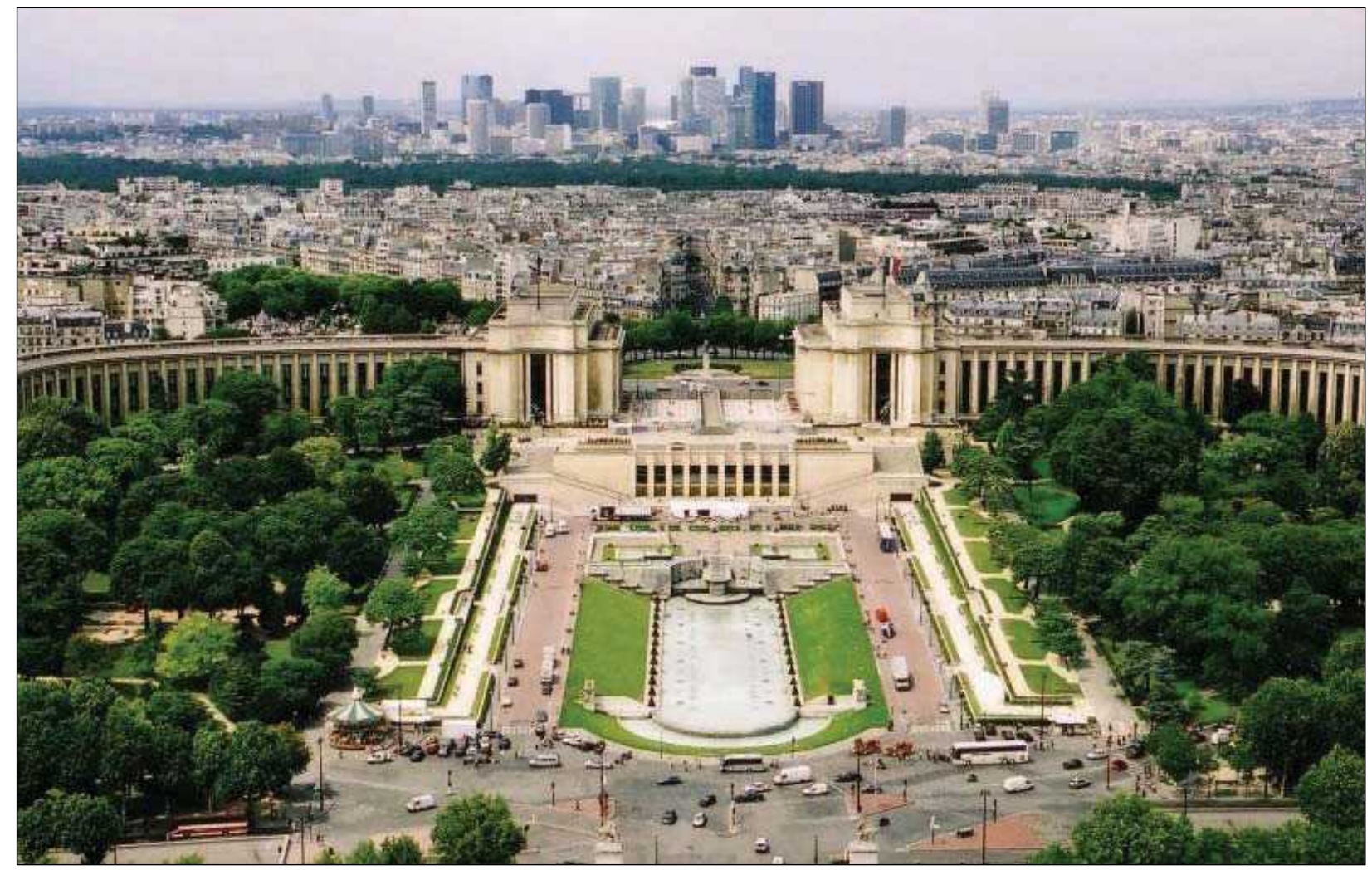

B

3 pav. Istoriniai miestovaizdžiai ir jų santykis su aukštybine statyba: A - Londonas iš "Londono akies", B - Paryžius iš Eifelio bokšto

Fig. 3. Historic townscapes and their relation with high-rise building: A - London from the "London Eye", B - Paris from Eiffel Tower 
Siekiant pateikti motyvuotą aukštybinių pastatų išdèstymo specialųji planą, buvo nuspręsta, kad svarbu ne tik parinkti aukštybinių pastatų vietas Klaipedos miesto karkase, bet taip pat apibrèžti teritorijų plètrą tarp aukštybinių pastatų (tiek patį užstatymą, tiek ir erdves, esančias tarp jo). Taip būtų nustatytas aukštybinio pastato ir aplinkos santykis, jo vizualinis poveikis bendrai miesto kompozicijai.

Klaipèdos miesto miestovaizdžiu struktūra. Išskirtos Klaipedos struktūrinès miesto dalys iš esmès atitinka vieną ar kelis miestovaizdžių tipus ir sutampa su jų ribomis. Miestovaizdžių pasiskirstymas kuria skirtingo charakterio zonas bei suteikia tam tikrą ìvairovę miesto vizualiniam ịvaizdžiui ir jo plètros galimybèms.

Visos erdvinès miestovaizdžių sistemos formavimo pagrindas yra nustatytų miesto dalių planavimo principai - morfotipai, kuriais remiantis miestovaizdžiai padalinami ị smulkesnius teritorinius vienetus. Morfotipas - tai požymis, charakterizuojantis teritorinį vienetą, kuris yra homogeniškas ne tik teritorijos panaudojimo intensyvumo požiūriu, bet ir neturintis savo sandaros skirtumų gamtiniu (morfogeninio reljefo tipo ribose) bei funkciniu atžvilgiu. Juo galima apibūdinti vientisą kvartalą, sklypų grupę arba vieną sklypą. Visi išskirti teritoriniai vienetai yra unikalūs (savo forma, tipu, užstatymu ir pan.), todel kiekvienam jų suteiktas vardas - indeksas (atspindintis kvartalo lokaciją pagal rajoną ir gatvę) individualiam charakterizavimui (4 pav.). Iš viso Klaipèdos mieste išskirta 1701 teritorinių vienetų, kurių skaidymo pagrindą sudaro esama urbanistinè struktūra, užstatymo morfotipo įvairovè ir esamo užstatymo prognozuojamų rodiklių stabilumas. Taip gana paprasta apibūdinti bendras konkretaus miestovaizdžio tendencijas, o tai tiesiogiai susiję su Klaipèdos vizualinio įvaizdžio plètros galimybemis.

Rengiant miesto struktūrinių dalių, miestovaizdžių skirstymo rajonais ir morfotipo identifikavimo schemas pastebèta jų tarpusavio ryšių nulemta seka:

\section{STRUKTŪRINĖS MIESTO DALYS (ZONOS) $\leftrightarrow$ MIESTOVAIZDŽIAI $\leftrightarrow$ MORFOTIPAI.}

Iš esmès miestovaizdžių charakterị nulemia gamtinès ir urbanistinès morfostruktūros sąsaja. Skirtingiems miestovaizdžių tipams būdingas ir skirtingas morfotipas. Miestovaizdị charakterizuoja trys tarpusavyje glaudžiai susiję veiksniai - užstatymo morfotipas, užstatymo aukštingumas ir užstatymo tankis (šiuo atveju užstatymo intensyvumas tera juos papildantis). Teritorijos morfotipas yra bene svarbiausias vizualinị identitetą reglamentuojantis veiksnys. Jame atsispindi tiek socialiniai, tiek ekonominiai, tiek kultūriniai, politiniai, juridiniai, nuosavybès bei kiti visuomeninį formavimąsi išreiškiantys rodikliai. Todèl išanalizuoti visi esami Klaipedos morfotipai ir jų deriniai, nes kiekvienas morfotipas turi skirtingas plètros galimybes.

Kadangi Klaipèda - tai miestas, kūręsis skirtingu šalių globos sąlygomis - tai ir buvusios Prūsijos, ir Vokietijos, ir galiausiai Lietuvos miestas, todèl neatsitiktinai kai kurie miesto užstatymo planavimo principai yra būdingi tik Klaipèdos miesto struktūrai (jų neteko aptikti kituose Lietuvos miestuose). Pagrindiniai yra 8 planavimo principai (sodybinis, miesto vilų, perimetrinis, taškinis, laisvo planavimo, konversinis, želdynų ir visuomeninių erdvių), o jų atmainų 35 , tarp kurių 21 užstatymo (5 pav.), 8 želdynų ir 6 visuomeninių erdvių atmainų tipai.

\subsection{Miesto teritorijų, atitinkančių kompozicinès plètros idèją, įvertinimas galimo užstatymo aukštybiniais pastatais požiūriu}

Aukštybinių pastatu statymo, ju atsiradimo mieste klausimai dažniausiai susiję su jų vieta susiklosčiusiame miestovaizdyje ir urbanistinès struktūros kontekste. Todèl svarbu ịvertinti kiekvieno kvartalo morfotipo plètros galimybes. Tikslinamos ịvairių miesto kvartalų ir sklypų plètros sąlygos, susijusios su aukštybinių pastatų statybos galimybèmis.

Aukštybinių pastatų išdèstymo specialiojo plano sprendinių konkretizavimo etape sprendiniai tiksli-

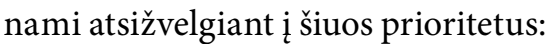

- miesto struktūrinių elementų užstatymo morfostruktūros kitimo prognozę;

- miesto struktūrinių elementų užstatymo perspektyvinio foninio aukštingumo kitimo prognozę;

- aukštybinès statybos plètojimo miesto urbanistinèje struktūroje konkretizavimą.

Miesto teritorijos, atitinkančios kompozicinès plètros ideją, vertinamos galimo užstatymo aukštybiniais pastatais požiūriu, remiantis šių teritorijų struktūrizavimu pagal kompozicinius kriterijus, ir esamos būklès analizès etape nustatyta saugomų teritorijų vertybine hierarchija miesto centrineje dalyje:

- I laipsnio vertès teritorija - tai miesto branduolys su karo stovyklos struktūra (gatvių tinklas, užstatymas) ir pilis; 


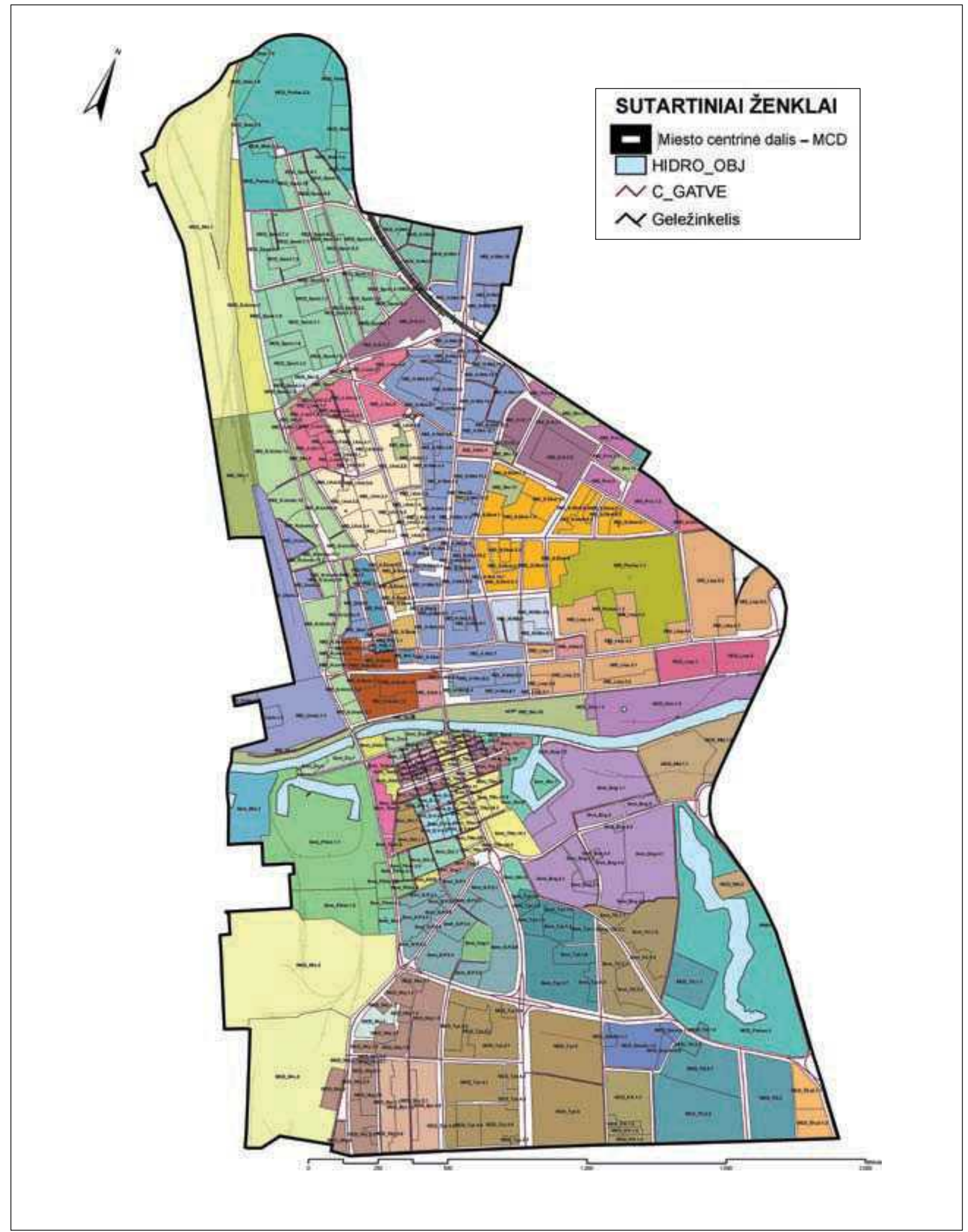

4 pav. Klaipèdos miesto kvartalų indeksavimas miesto centrinejje dalyje

Fig. 4. Indexation of blocks in the central part of Klaipeda city 


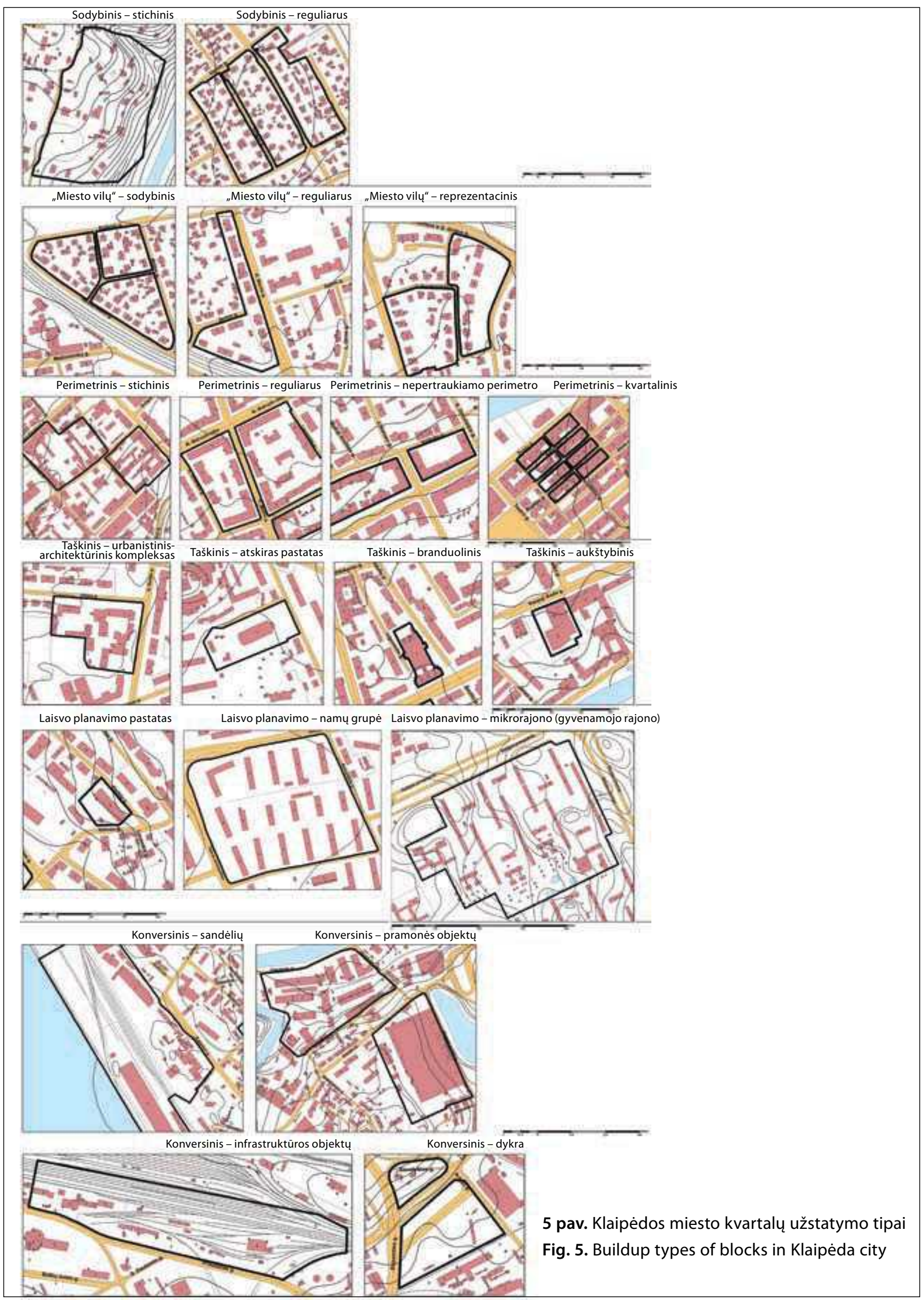


- II laipsnio vertès teritorija - branduolio apsaugos žiedas (buvusi Krūmamiesčio teritorija ir Frydricho priemiestis su bastioniniais ittvirtinimais);

- III laipsnio vertès teritorija - įeina ị branduolio apsaugos žiedą (Vilhelmštato ir Didžiosios Vitès teritorija, buvę istoriniai priemiesčiai);

- IV laipsnio vertès teritorija - miesto centrinis rajonas (geležinkelio linijos, Pušyno, L. Giros, S. Dariaus ir S. Girèno gatvių, geležinkelio linijos, Priestoties, Trilapio, Mokyklos, Paryžiaus Komunos, Rūtų gatvių bei Kuršių marių ribojama teritorija).

Toks struktūrinis teritorijų skaidymas nèra prieštara $1995 \mathrm{~m}$. moksliniame darbe nustatytoms urbanistikos paveldo saugotinoms teritorijoms (Miškinis, Bučas 1995). Juo siekiama suteikti struktūrinį vientisumą susiklosčiusiems miestovaizdžiams, nes dalis teritorijų yra labai smulkiai susiskaidžiusios dèl nelygiavertiško urbanistinès struktūros komponentų ${ }^{3}$ išlikimo iki šių dienų. Ši hierarchija apima skirtingų laikmečių paženklintas teritorijas. Siekiant suformuoti vientisą konkrečios dalies miestovaizdị, turètų dominuoti vienas morfotipas, o tai būdinga struktūrinị užbaigtumą turinčioms (ir galutinai susiformavusioms) struktūroms. Tokių Klaipédoje nèra daug, nes beveik visose jų galima aptikti ne vien tik vieno ar kito morfotipo intarpus (užsienio literatūroje dar vadinamus implantais implants (Verbakel, Derman 2008)), bet dažnai nemažus junginius sudarančius elementus, kurie iš esmès sujaukia vientisą miestovaizdžio charakterị. Neretai sąmoninga ar atsitiktinè skirtingų morfotipų tarpusavio kaita lemia struktūrinị ir erdvinị chaosą. Tai akivaizdu visuose išskirtuose Klaipedos miestovaizdžiuose ir tai tiesiogiai veikia miesto vizualinị ịvaizdị.

\subsubsection{Miesto struktūrinių elementų užstatymo morfostruktūros kitimo prognozé}

Išanalizavus Lietuvos miestams (Vilniui, Šiauliams, Trakams, Palangai $\left.{ }^{4}\right)$ naudojamas užstatymo rodiklių

\footnotetext{
${ }^{3} 1995$ m. moksliniame darbe (Miškinis, Bučas 1995) ir tais pačiais metais paskelbtame straipsnyje (Bučas 1995) išskirta 10 urbanistinès struktūros komponentų, kurių savybès vertintinos kaip urbanistinès struktūros indikatoriai - tai gatvių tinklas, posesinè struktūra, aikščių, gatvių ir posesijų apstatymo pobūdis, statiniu kompleksai ir ansambliai, paminklai ir kitos pavienès istorijos ir kultūros vertybès, žaliosios architektūros elementai, orografinès formos, panoramos ir siluetai, atskirų miesto dalių erdvinès kompozicijos visuma, kultūrinis sluoksnis.

${ }^{4}$ Miestai, kuriems parengti bendrieji planai (vadovaujantis nauju Teritoriju planavimo ịstatymu, patvirtintu $2004 \mathrm{~m}$. gegužès 1 d., îsakymo Nr. 21-617) nèra sukonstruoti kaip eiliniai žemès paskirčių brěžiniai (mozaika), o matant miesto regioninę padètị, erdvinès struktūros sandaros bruožus, vertybinius elementus ir jų apibrèžtą potencialą.
}

išraiškas ir reikšmes, atlikus išsamius esamų užstatymo rodiklių tyrimus Klaipedos mieste, sudaryta lentelè su prognozuojamais plètros rodikliais (žr. lentelę). Užstatymo morfotipas buvo identifikuotas kaip pirminis požymis, išreiškiantis vizualią informaciją tuo tikslu, kad sèkmingai atpažintas morfostruktūros tipas yra priemonè užstatymo rodiklių kitimo prognozei nustatyti. Šių rodiklių absoliučios reikšmès nustatomos vadovaujantis taikytomis Vokietijos normomis, ypač rytinès dalies miestų patirtimi, taikoma Lietuvos miestams (Vilniaus ... 2000, 2001; Pakalnis 2000).

Tačiau pastebèta, kad ribiniai rodikliai, būdingi vienam morfotipui miesto centrineje dalyje, ne visada gali būti taikomi ir buferineje ar periferineje zonoje panašiam morfotipui, t. y. to paties morfotipo ar jo atmainos rodikliai neprivalo būti tapatūs, nes šiuo atveju daug ką lemia morfotipo lokacija, nuo kurios priklauso rodiklių svyravimai.

Klaipèdos kvartalų struktūroje galima išskirti vieną itin reikšmingą požymị - tęstinumo stygiụ ir didelị fragmentiškumą, arba kitaip, užstatymo intensyvumo stoką lemiantị struktūros neužbaigtumą, vientisumo nebuvimą. Nes miestas visų pirma yra koncentracija, o jos stygius užstatymo požiūriu yra nebrandžios struktūros požymis. Pagrindinius užstatymo tipus, jų vientisumą lemia konkretaus užstatymo tipo lokacija.

Miesto centrinėje dalyje galima identifikuoti ypač platų planavimo principų spektrą, nes tai ịvairių politinių, ekonominių interesų sritis (6 pav.). Klaipėdos miesto centrinè dalis labai nukentejo nuo karo, vèliau sovietiniais metais padaryta intervencija ị miesto audinį nepataisè padèties, o tik dar labiau ją pablogino. Skurdus dominančių arsenalas, pavienès realizacijos pokario bei nepriklausomybès metais lyg bandymas atstoti sunaikintą erdvinę kompoziciją, bet jau kitaip.

Miesto centrinè dalis sulauke ịvairių mokslininkų ir tyrèjų dèmesio. Ypač vertingi N. Zubovienès ir V. Zubovo 1973-1975 m. (Klaipédos ... 1975), V. Šliogerio 1993 m. (Klaipèdos ... 1993), L. Šliogerienès 1994 m. (Klaipèdos ... 1994) Senamiesčio regeneracijos projektai bei 1995 m. J. Bučo, A. Miškinio mokslinis tiriamasis darbas (Miškinis, Bučas ... 1995).

$2005 \mathrm{~m}$. moksliniame darbe apie miestų morfostruktūros transformacijas (Alistratovaitè 2004) pateikiami Klaipedos miesto centrinès dalies pokyčiai nuo $1942 \mathrm{~m}$. iki $2002 \mathrm{~m}$. Todèl kvartaluose vyrauja net keletas skirtingų užstatymo tipų, dèl to kvartalas tampa ne vienalytis, o morfotipas, neigavęs struktūrinio vientisumo, tai itin akivaizdu miesto panoramose, neprisideda prie miestovaizdžių identiteto stiprinimo. 
Lentelè. Klaipedos miesto teritorijos plètros rodikliai

Territorial development indixes of Klaipèda city

\begin{tabular}{|c|c|c|c|c|c|c|c|c|c|c|c|c|}
\hline \multirow{2}{*}{\multicolumn{2}{|c|}{$\begin{array}{l}\text { Kvartalo } \\
\text { indeksas }\end{array}$}} & \multirow{2}{*}{\multicolumn{2}{|c|}{$\begin{array}{l}\text { Užstatymo } \\
\text { morfotipas }\end{array}$}} & \multicolumn{6}{|c|}{ Užstatymo rodikliai } & \multirow{3}{*}{$\begin{array}{c}\text { Verti- } \\
\text { kalių } \\
\text { statymo } \\
\text { būdas }\end{array}$} & \multirow{3}{*}{$\begin{array}{l}\text { Verti- } \\
\text { kalių } \\
\text { san- } \\
\text { tykis } \\
\text { su fonu }\end{array}$} & \multirow{3}{*}{$\begin{array}{c}\text { Pasta- } \\
\text { bos }\end{array}$} \\
\hline & & & & \multicolumn{2}{|c|}{ tankumas (\%) } & \multicolumn{2}{|c|}{$\begin{array}{l}\text { intensyvumas } \\
\text { (koef.) }\end{array}$} & \multicolumn{2}{|c|}{$\begin{array}{l}\text { aukštingumas } \\
\text { (a.) } \\
\end{array}$} & & & \\
\hline $\begin{array}{l}\text { bendri- } \\
\text { nis }\end{array}$ & $\begin{array}{l}\text { sudè- } \\
\text { tinis }\end{array}$ & $\begin{array}{l}\text { esa- } \\
\text { mas }\end{array}$ & $\begin{array}{l}\text { progno- } \\
\text { zuojamas }\end{array}$ & $\begin{array}{l}\text { esa- } \\
\text { mas }\end{array}$ & $\begin{array}{c}\text { progno- } \\
\text { zuojamas }\end{array}$ & $\begin{array}{l}\text { esa- } \\
\text { mas }\end{array}$ & $\begin{array}{l}\text { progno- } \\
\text { zuojamas }\end{array}$ & $\begin{array}{l}\text { esa- } \\
\text { mas }\end{array}$ & $\begin{array}{c}\text { progno- } \\
\text { zuojamas }\end{array}$ & & & \\
\hline 1 & 2 & 3 & 4 & 5 & 6 & 7 & 8 & 9 & 10 & 11 & 12 & 13 \\
\hline
\end{tabular}

I laipsnio vertès teritorija visoje miesto centrinèje dalyje išsiskiria bene vientisiausia erdvine charakteristika - XIV a. siekianti romėniškoji gatvelių sistema lèmé unikalų užstatymą. Nors laiko dimensijoje jis yra kažkiek transformuotas, tačiau šis pokytis nèra pavojingas ir svarbus teritorijos atpažįstamumui, jo tapatumo išsaugojimui. Teritorijos vertè yra jos vientisas foninis 2-3 aukštų užstatymas smailais stogais, formuojantis raudonų stogų panoramą, kurios aukštingumas siekia iki $16 \mathrm{~m}$ aukštị, išskyrus Mejjerheferio pastatą, siekiantị $30 \mathrm{~m}$ aukštị. Remiantis istorine erdvine šios teritorijos užstatymo kompozicija ir 1973-1975 m. Klaipėdos miesto Senamiesčio regeneracijos projektu (Klaipèdos ... 1975) specialiajame plane siūloma atstatyti buvusią Šv. Jono bažnyčią ar kitą vertikalų akcentą (60 m aukščio), kurio „viršūnei“ būtų keliami itin dideli architektūriniai reikalavimai, o paskirtis neturètú būti gyvenama. Visoje kitoje dalyje ir toliau respektuoti susiformavusị foninị aukštị ir Senamiesčiui būdingą spalvinị sprendimą.

Piliavietè yra ne tik miesto centrinès dalies $a s ̌ i s$, bet ir visos Klaipèdos teritorijos kulminacija. Vadovaujantis 1993 m. Klaipèdos regeneraciniu projektu (Klaipèdos ... 1993) ir remiantis istorine erdvine šios teritorijos užstatymo kompozicija, siūloma atsižvelgti i ypatingą istorinę bei kultūrinę piliavietès reikšmę ir ị paminklui apsaugoti bei atstatyti būtinas sąlygas - siūloma iškelti pramoninius objektus ir nebeleisti jokios ūkinès bei gamybinès veiklos šioje teritorijoje. Pagal $2002 \mathrm{~m}$. patvirtintą detalųji planą (2002 0214 Klaipėdos miesto valdybos sprendimu Nr. 69) Klaipèdos piliavietès teritorijoje numatytas didžiojo pilies bokšto atstatymas, leistinas bokšto aukštis $-47 \mathrm{~m}$. Ši realizacija ateityje tik sustiprintų pilies vaidmenị ne tik Senamiesčio dalyje, bet visoje Klaipėdoje; kartu turètų teigiamą poveiki silueto ir panoramos formavimuisi.

II laipsnio vertès teritorija laikoma branduolio apsaugos žiedu - dešinejje Danès upès pusèje buvusi Krūmamiesčio teritorija (dabar tai dalis Naujamiesčio) ir kairejje Danės pusėje Frydricho priemiestis su bastioniniais ittvirtinimais.

Naujamiesčio dalies urbanistinès morfostruktūros teritorija išsiskiria nedidelio aukščio 3-4 aukštų šlaitiniais čerpių stogais (tai šiek tiek artima I laipsnio vertès teritorijos fonui). Kadaise savo aukščiu išsiskiriantis Klaipèdos viešbutis bei dramos teatro bokštas aukščiausių pastatų pozicijas šioje miesto dalyje užleido neseniai realizuotų „K“ ir „D“ pastatų kompleksui. Dabar jie formuoja pagrindinị aukštybinių pastatų „mazgą“" istorineje Klaipèdos miesto dalyje, todèl svarbu iš naujo ivvertinti šios zonos kompoziciją.

Ypač negatyvus reiškinys yra prie Danès upès ir marių esančios konversinio užstatymo tipo pramonès, uosto sandèlių teritorijos. Nuolatinè uosto teritorijų plètra tiek kapitaliniais, tiek menkaverčiais statiniais užèmè ir sunaikino didžiąją dalị Klaipèdos bastioninių ịtvirtinimų. Regeneruojant teritoriją siūlomas ne didesnis nei 3 aukštų užstatymas, kuris panoramoje nuo Kuršių nerijos sudarytų teritorijų aukštingumo planiškumą.

Frydricho priemiesčio teritorija taip pat yra labai nevienalytè paveldo požiūriu, dominuoja perimetrinis stichiškas morfotipas su perimetrinio reguliaraus, laisvo planavimo intarpais. Tačiau visuomeninių erdvių tipų ịvairovė (aikštè, skveras, alèja, molas, prieplauka) laikoma tolesniu morfotipų tobulinimo pagrindu II laipsnio vertès teritorijoje.

III laipsnio vertès teritorija - tai Vilhelmštatu bei Didžiąja Vite vadintų teritorijų junginys, ịeinantis ị branduolio apsaugos žiedą. Kaip ir ankstesnès ši teritorija nèra lygiareikšmè ir vienalytė morfotipų atžvilgiu. Bene mažiausią invaziją sovietiniais metais patyrusi laisvo planavimo pastatais yra Vilhelmštato dalis ị rytus nuo H. Manto g. Joje susiformavę ir išlikę unikalūs miesto vilų ir taškinis morfotipai. Visoje likusioje dalyje nèra dominuojančio morfotipo.

Didžiosios Vitès teritorija yra bene labiausiai nukentèjusi nuo karo, o padarytų nuostolių neeliminavo sovietiniais metais padaryta intervencija su Naujojo 


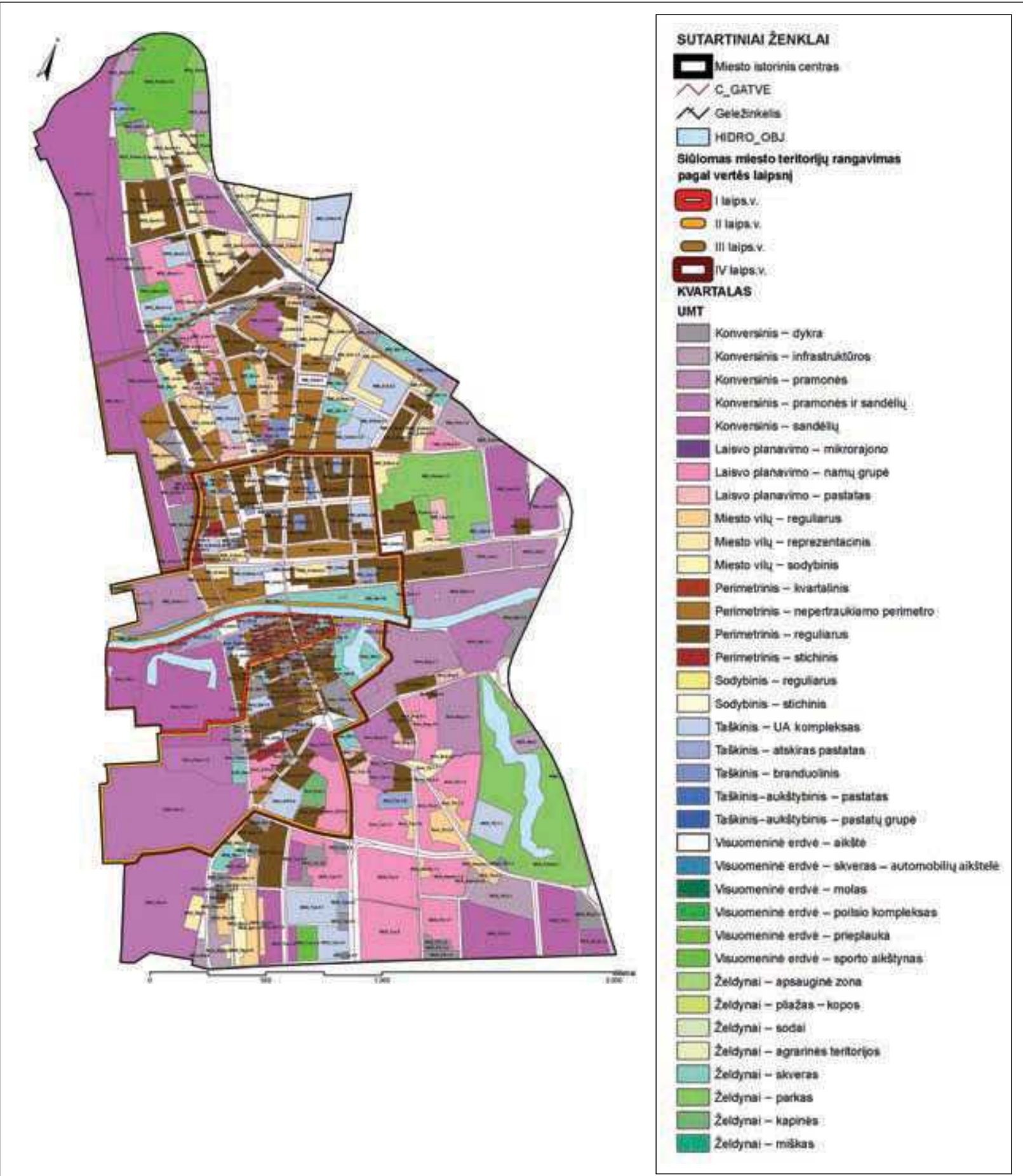

A

6 pav. Kvartalų užstatymo tipas miesto centrineje dalyje (MCD): $A$ - esamas, $B$ - perspektyvinis

Fig. 6. Buildup types of blocks in the central part of the city: A - existing type, $B$ - perspective type 


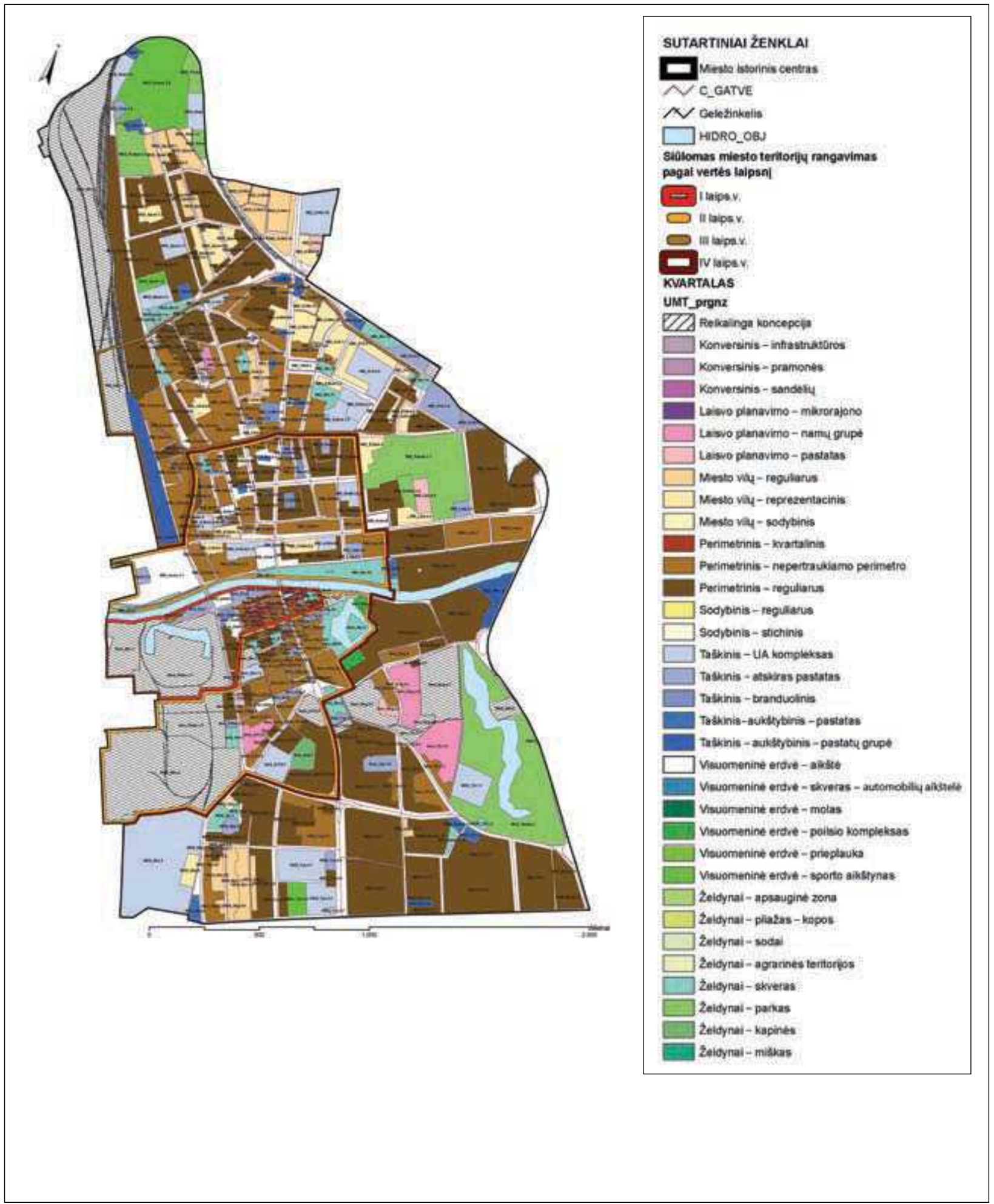


Uosto gatve. Nors Vités teritorijai pagal Klaipėdos bendrąji planą (patvirtintą $20070405 \mathrm{Nr}$. T2-110) ir numatyta tikslingai keičiant teritorijų funkcinę paskirtị atsisakyti sandèliavimo ir gamybinès veiklos bei atkurti istorinę urbanistinę struktūrą, nesumažinant laisvai prieinamų viešųjų erdvių plotų, vizualinių perspektyvų i piliavietę ir vandens erdvių, tačiau vykusio konkurso medžiaga nelabai įtikina savo galimybèmis realizuoti ir visiškai ịvykdyti bendrojo plano uždavinius ir nenulemia užstatymo aukštingumo.

IV laipsnio vertès teritorija supa I, II ir III laipsnio vertès teritorijas, pasižymi ypač margu planavimo principų spektru ir gali būti dalinama ị šiaurinę, rytinę ir pietinę dalis. Joje mažiausiai paveldo statusą turinčių teritorijų, tai teritorijos, turinčios daugiau kultūrinès vertès požymių.

Šiaurinè dalis - tai gana skirtingos teritorijos: buvusi Bomelio Vites (vyrauja sovietiniais metais vykdytu statybų rezultatas), Zandvèro (išlikęs 2 aukštų (iki $8 \mathrm{~m}$ aukščio) miesto vilų užstatymo tipas su perimetriniu morfotipu, suformuotu sovietiniais metais) ir Igulos gatvès (sodybinio ir miesto vilų morfotipų samplaika) bei kareivinès (XIX a. pradžios urbanistinis architektūrinis kompleksas).

Rytinèje IV laipsnio vertès teritorijos dalyje dominuoja laisvo planavimo ir konversinis (pramonès ir sandèlių) morfotipai, tarp kurių įsiterpęželdynai (Trinyčių ir Skulptūrų parkai). Beveik visos Danès upès prieigos atkarpoje nuo marių iki geležinkelio dominuoja pramoninè funkcija (išskyrus siaurą ruožą ties Senamiesčiu). Šiai atkarpai reikalinga nauja koncepcija.

Pietinèje IV laipsnio vertès teritorijos dalyje išsiskiria Smeltès tipinių namų rajonas. Vienintelè dominantė yra Marijos Taikos Karalienès bažnyčia, suprojektuota 1958 m., aukščiu prilygstanti ikikarinei Šv. Jono bažnyčiai grakščiais bokštais, išsiskirianti IV laipsnio vertès teritorijos pietinejje dalyje, kur dominuoja laisvo planavimo morfotipas, sąlygiškai laikomas perimetriniu. Siektina atstatyti perimetrinę užstatymo struktūrą, kuri atitiktų šios dalies vertès statusą tarp kitų teritorijų.

Daugelyje miesto centrinès dalies kvartalų (ypač I, II ir III laipsnio vertès teritorijose) reikia lokalaus šios sistemos struktūroje likusių užstatymo spragų užpildymo. Išimtinai visas pakrantès ruožas, einantis per visas keturias skirtingos vertès teritorijas, yra konversinè teritorija su dykrų, sandèlių, pramonès, infrastruktūros morfotipo atmainomis. Todèl naujos kokybès, tačiau vadovaujantis gretimos struktūros užstatymo morfotipais, užstatymas formuotinas visoje pakranteje.
Vengti pernelyg ekstensyvių, periferijos sodybiniam užstatymui būdingų užstatymo principų.

Šiaurinei miesto daliai priskiriama zona susideda iš dviejų labai skirtingų morfostruktūros požiūriu dalių (gamtinès ir urbanistinès): pirmoji - tai gamtinès morfostruktūros kilmés teritorija, vadinama Klaipédos mišku, antroji - tai teritorija tarp Klaipedos miško ir Minijos upès iki geležinkelio linijos.

Klaipèdos miškas visoje miesto struktūroje išsiskiria vientisu želdynų masyvu, ị kurị kur ne kur įsiterpę pavieniai morfotipai - tai visuomeninès erdvès (poilsio kompleksai) ir stichiškai suformuotas sodybinis užstatymas.

Antroji šiaurinès miesto zonos struktūrinè dalis ribojasi su Klaipèdos mišku ir pagal netolygų teritorijos ịsisavinimą skirstoma ị šiaurinį, centrinị ir pietinị miestovaizdžius, kurie pagal urbanizacijos laipsnị yra labai skirtingi, todèl siūloma šį skirtumą išlaikyti. Raiškiausias yra pietinis miestovaizdžio tipas, apimantis geležinkelį ir dalį su juo susijusių teritorijų, kuriose vyrauja konversinis ir laisvo planavimo morfotipai. Klaipedos panoramose labai išsiskiria sovietiniais metais statytas raudonų plytų gyvenamasis daugiabučių Miško kvartalas, tapęs miesto urbanizacijos ženklu. Remiantis miesto kompozicinio karkaso modeliu aukštybinès statybos plètrai (1 pav.) šiaurinèje miesto zonoje numatomos šalutinès aukštybinių pastatų koncentracijos zonos, o Miško kvartalas šioje kompozicijoje formuoja Klaipedos ịvaizdžio mazgą.

Rytinèje miesto zonoje dominuoja neịsisavintos teritorijos, kaip tai būdinga visiems miestų pakraščiams (taip pat šiaurinei daliai). Ją sudaro dvi dalys: pirmoji nuo Minijos upès ị rytus, antroji dalis nuo geležinkelio linijos ị rytus, jų skiriamoji riba - Baltijos pr. Pirmajai daliai - būdingi keli miestovaizdžio tipai, tačiau juos vienijantis elementas yra Danés upé, kuri uostamiestyje (visų miestovaizdžių atžvilgiu) yra kaip svetimkūnis, o ne integruota sistemos dalis. Aplink ją besiformuoja padrikas užstatymas (tiek šiaurinejje miesto dalyje, tiek rytinejje), todèl perspektyvoje reiktų griežčiau reglamentuoti panašias miestui svarbias savo kompozicine reikšme teritorijas. Vengti uždarų, intensyviai užstatytų teritorijų, vadovautis ,šukų“ principu formuojant užstatymą prie jautrių gamtinių elementų.

Pagrindinis rytinès miesto zonos elementas bei išskirtųjų dalių riba yra ịvažiavimo ị Klaipèdą mazgas ir atkarpa - miesto vartai. Tai vienas iš 8 patekimų $i$ Klaipedą. Klaipèdos miesto ịvaizdis rytų puseje gana skurdus, todèl svarbus tampa patekimo į miestą teritorijų išryškinimas, o miesto prieigų ženklinimas yra vienas iš būdų vizualinio identiteto formavimo proce- 
se. Dèl galimos konversijos įvažiavimo ị miestą atkarpa turi aukštybinių pastatų atsiradimo potencialą, todèl svarbu ivertinti nagrinejamo teritorijos silueto formavimo galimybes viso miesto kontekste. Sąmoningas šiu teritorijų planavimas ịpareigoja pasirinkti urbanistinès struktūros atžvilgiu teisingą miesto vartų formavimo būdą. Vienas iš principų (artimas viduramžių miesto vartų išraiškai) - aukštesniu nei foninis teritorijos užstatymas objektu pažymèti patekimą ị miestą ar jo dalį. Ši teritorija turi tokias galimybes, juolab kad aplinkui urbanizuojamos prieigos tampa chaotiško užstatymo pradžia, trinančia Klaipèdos miesto ribą. Šioje teritorijoje rekomenduojama radikaliausia morfotipo kaita visoje Klaipedoje.

Pietinei miesto daliai priskiriama zona ribojama geležinkelio linijos ir Kuršių marių. Ji skaidoma ị dvi dalis dèl ne vienu laiku ịsisavintų teritorijų ir skirtingų miestovaizdžių tipų, kurių skiriamoji riba yra Baltijos pr. Pirmoji yra arčiau miesto centrinès dalies ir jai sudaro buferinę zoną. Joje dar išlikęs gatvių tinklas bei užstatymo fragmentai, suformuoti iki $1945 \mathrm{~m}$. Nors išskirta kaip viena dalis, ji susideda iš kelių miestovaizdžių dèl skirtingų morfotipų charakterio.

Priešingai, antroji dalis yra tipinis sovietinis gyvenamasis rajonas su stichiškai pastatytais daugiaaukščiais, besiskiriantis vien tik gyvenamųjų namų dèstymo kompozicija. Akcentuoti reikètų Baltijos pr. pagrindinę miesto rytų-vakarų krypties ašĭ kurioje turetų būti formuojama teritorija, alternatyvi miesto centrinei daliai savo funkcijų gausa ir ịvairove.

Pakrantès ties Kuršių mariomis ruožas, kuris abejose pietinès miesto zonos dalyse yra uosto teritorijos reikmėms naudojama teritorija, priskiriamas konversiniam pramonès ir sandèlių morfotipui. Vienintelès miestui naudojamos prieigos yra ties II-ąja perkèla (300 m) ir Senąja Smelte (Žvejų uostu). Teritorija, esanti už Jūrininkų pr., šiandien visiškai neįsisavinta ir priskiriama konversiniam morfotipui, nors pagal Klaipedos bendrąji planą čia numatytos bendro naudojimo ir apsauginių želdynų teritorijos. Akcentuotina tai, kad Klaipèdos miestas neturi aiškios gamtinès struktūros ašies. Nors ir galima įžvelgti išilgini žaliąji koridorių per miestą, jis nèra vientisas ir aiškus, daugiau susiformavęs dèl chaotiško planavimo ir atsitiktinumų.

Vakarinei miesto daliai priskiriama zona ribojama Klaipėdos miško ir Baltijos jūros bei Kuršių nerijos dalies (Smiltynè). Tai dvi fiziškai atskiros miesto dalys, skalaujamos Baltijos jūros ir sudarančios miesto fasadą jūrų transportui bei stabiliausios miesto dalys morfotipo kitimo požiūriu. Smiltyneje vyrauja žalioji struktūra, kuri yra pagrindinis silueto formantas, todèl čia aukštybinè statyba nenumatoma, tik rekomenduojamas atskiru morfotipu, îsiterpusiu i is și gamtos kampeli, tobulinimas iš vidaus (kompozicinemis, struktūrinèmis bei estetinemis priemonemis nedidinant pastatu aukštingumo ir respektuojant vietos mastelị).

Kitą vakarinę miesto zonos dalị supa ir pagrindinị foną siluete sudaro želdynai (Klaipedos miškas). Ši dalis nuo Klaipèdos miško atskirta urbanistine morfostruktūra. Joje dominuoja pajūrio specifikos morfotipas (želdynai, kopos, pliažas). I želdynų masyvą įsiterpusios gyvenvietès - Giruliai, I ir II Melnragès formuoja 2-3 aukštų (iki $10 \mathrm{~m}$ ) foninị aukští, sodybinio taškinio morfotipų kompozicijas. Ypatingas demesys skiriamas gamtiniam elementui kaip pagrindiniam teritorijos silueto formantui šioje atkarpoje. Gamtinis fonas (tiek želdynų grupè, tiek reljefas) gali būti kaip baigtinis elementas - paskutinis planas siluete - arba kaip vienas iš planų tarp kitų miesto erdvinès struktūros elementų, tai priklausytų nuo kraštovaizdžio kitimo analizių ir pasekmių studijų (7 pav.).

Išskiriama tikịplaukimo į miestą teritorija - tai jūros vartai, vienas iš aštuonių kelių, vedančių į Klaipedos miestą. Ties ịplaukimu ị Klaipèdos miesto teritoriją šiaurinèje dalyje numatomas regeneracijos procesas. Čia tikslinga kurti daugiafunkcès paskirties morfotipus su išreikštu objektu teritorijos svarbai pažymėti. Galimas jūros vartų nužymèjimas - vertikalios taškinès (pavienès) arba horizontalios dominantès atsiradimas.

Nustatytos teritorijos, kuriose nèra aiškiai išreikšto morfotipo. Tokių teritorijų prognozè bei reglamentavimas yra komplikuotas. Tuo atveju, kai nèra jokios analizès, koncepcijos ir pan., pritaikoma Bendrojo plano nuostata, kad vertingose teritorijose negalima pradèti planuoti aukštybinių pastatų arba numatyti tokị aukštingumą, koks yra gretimose teritorijose. Teritorijos galimybes reikia tikrinti atskiromis studijomis parengiant tos teritorijos koncepciją.

Apibendrinant galima konstatuoti, kad žvelgiant i Klaipèdos panoramą nuo Kuršių marių nejučia kyla mintis, sietina su sovietiniais metais nerašyta taisykle, kad bet kuris pramonés objektas urbanistineje morfostruktūroje turi pirmumo teisę.

\subsubsection{Miesto struktūrinių elementų užstatymo perspektyvinio foninio aukštingumo kitimo prognozè}

Identifikuotiems užstatymo morfotipams nustatyti esami ir prognozuojami kiekybiniai rodikliai (maksimalus leistinas užstatymo aukštingumas, tankumas, intensyvumas). Morfotipas traktuojamas kaip 


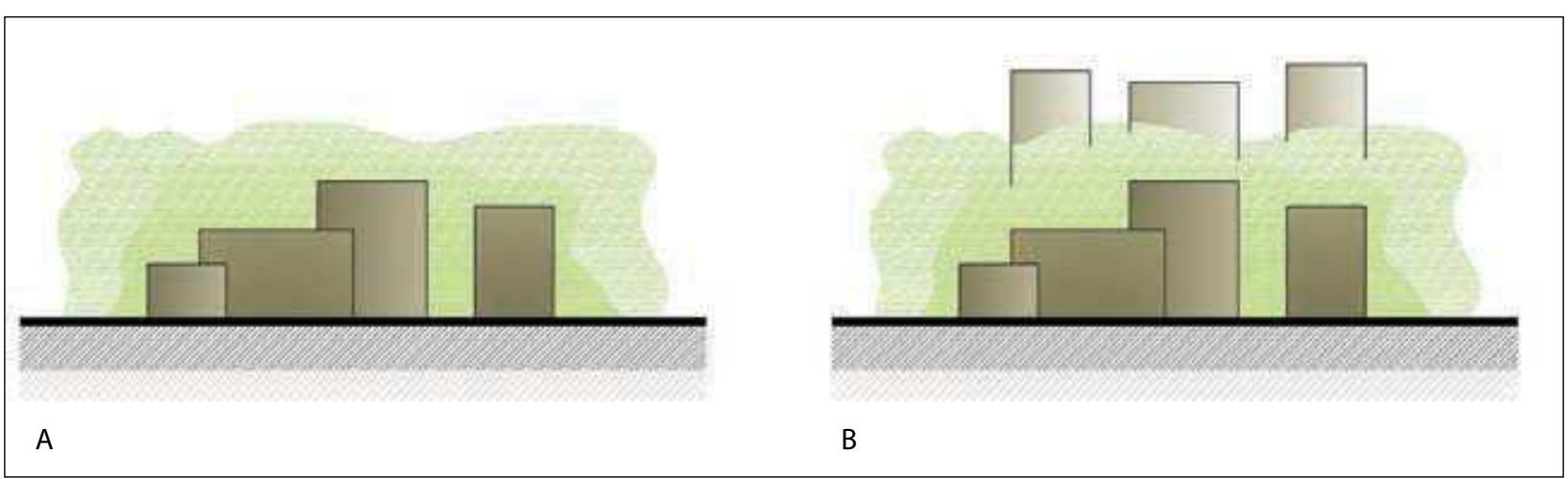

7 pav. Gamtinių elementų pozicijos galimybès miesto siluete: A - gamtinis elementas kaip paskutinis (užbaigiantis) silueto planas; $B$ - gamtinis elementas kaip vienas iš planų miesto siluete

Fig. 7. Possible exposure of natural elements in the city silhouette: A - natural element as the last (closing) silhouette plan; $\mathrm{B}$ - natural element as one of the plans for the city silhouette

pagrindinis veiksnys nustatant prognozuojamus užstatymo rodiklius. Urbanistu jau yra sutarta, kad kiekvienas užstatymo morfotipas turi jam būdingą užstatymo aukštingumą ir tankị, kuris leidžia kalbèti apie šiems tipams leistinas foninio aukštingumo plètros galimybes. Aukštybinè statyba sietina su užstatymo morfotipui būdingu vidutiniu ir absoliučiu (ribiniu) foniniu aukščiu, nes vertikalia dominante laikomas pastatas, savo aukščiu išsiskiriantis užstatymo fone (šiuo atveju taip pat galioja žemės naudojimo paskirties veiksnys, nors jo reikšmè nèra vienoda).

Vertingose Klaipèdos dalyse, kur būtina išlaikyti vieną ar kitą dominuojantị užstatymo morfotipą, rekomenduojama respektuoti ir foninio aukštingumo charakteristikas.

Užstatymo rodiklių reglamentavimas nèra paremtas tik vienu kiekybiniu parametru - pastato aukščiu. Be užstatymo perspektyvinio foninio aukštingumo kitimo prognozès miesto struktūriniams elementams (8 pav.), buvo atlikta ir užstatymo perspektyvinio foninio intensyvumo ir tankumo kitimo prognozès $(9$, 10 pav.), tačiau jos plačiau nèra aptariamos dèl ribojamos straipsnio apimties.

Miesto centrinè dalis yra daugiaplanè ir ịvairiapusè, pasižyminti miestovaizdžiu gausa. Daugelio jų morfotipas tobulinamas iš vidaus pagal esamo užstatymo galimybes. Kompoziciškai svarbiose teritorijose galimas esamo morfotipo įvertinimas iš naujo, tačiau tam reikalinga svari argumentacija, nes gali kisti ir nusistoveję užstatymo principai jam artimuose kvartaluose. Stabiliausias raidos požiūriu ir vientisa morfostruktūra pasižymi Klaipèdos Senamiestis. Senamiesčio apsauga tampa svarbiausių gretimybių aukštybinę plètrą lemiančiu veiksniu. Tenka apgailes- tauti, kad Senamiestis kaip struktūrinis vienetas nei kompoziciškai, nei struktūriškai miesto morfostruktūroje nèra apibrèžtas, tai niveliuoja ir paskandina ji kitų laikmečių urbanistinèje terpeje (8 pav.). Toliau trumpai pristatoma miesto struktūrinių elementų užstatymo perspektyvinio foninio aukštingumo kitimo prognozė kiekvienai miesto centrinès dalies teritorijai.

I laipsnio vertés teritorijos urbanistinè morfostruktūra ir susiklostęs miestovaizdis iki dabar yra apžvalgos taškų ,iš vidaus ị išorę “ vizualinès erdvès identiteto pagrindas. Kadangi teritorija dèl gamybos ir sandeliavimo veiklos ir tam skirto užstatymo nèra suvokiama nuo Smiltynès, siūloma iškelti pramoninius objektus, o teritoriją panaudoti miesto reikmėms. Joje aukštinimas neturi viršyti nusistovejjusio raudonų stogų foninio aukščio. Didinti I laipsnio vertès teritorijos užstatymo foninị aukšti - neleistina, tik rekomenduojama statyti papildomus 2 akcentus: pirmą - piliavietès teritorijoje didịji pilies bokštą bei antrą - buvusioje Šv. Jono bažnyčios vietoje (aptarta 1.1.1. skirsnyje).

Nors sovietiniais metais ir stipriai "pakoreguota“ II laipsnio vertes teritorijos urbanistine morfostruktūra bei susiklostęs miestovaizdis, jo foninị aukštingumą nerekomenduojama didinti, nes pirmaisiais pokario dešimtmečiais (sovietiniais metais) suformuotas raudonų stogų foninio aukščio horizontalumas išlieka dominuojančiu šios teritorijos vizualinès erdvès identiteto pagrindu. Atskiri kvartalai dar nèra pasiekę foninio aukščio lygio, todèl rekomenduojama didinti jo horizontalumą ir taip išvengti kai kur tiek masteliu, tiek aukštingumu išsiskiriančių sovietinių metų padarinių.

Raudonų stogų foninio aukščio horizontalumas būdingas ir III laipsnio vertès teritorijai su kiek smulkes- 
nio mastelio užstatymo intarpais, išlaikiusiais tą patị aukštingumą Priestoties g. Tad vienodo lygio fonini užstatymą iš esmès galima laikyti viso Naujamiesčio vizualinès erdvès identiteto pagrindu. Vitès teritoriją siūloma formuoti 3 aukštų užstatymu, respektuojančiu išlikusios struktūros komponentus (jau, beje, tik gatvių tinklą, nes pavieniai išlikę pastatai neseniai nugriauti). Kompoziciniais ryšiais reikia susieti Zandvero teritoriją su Kuršių mariomis (ties J. Janonio, S. Daukanto ir Naujosios Sodo gatvėmis). Kadangi Klaipeda yra linijinis miestas ir visa H. Manto g. išklotinè yra vienoda ir tolygi savo išraiška, tai neatspindi skirtingų miestovaizdžių užstatymo (Krūmamiesčio, Vilhelmštato), todèl rekomenduojami pavieniai akcentai, nesuardantys būdingo horizontalumo, bet pabrèžiantys sąsają su Kuršių mariomis nebaigtuose formuoti urbanistiniuose ansambliuose prie viešųjų erdvių (M. Mažvydo alëjoje ir H. Manto gatveje).

Išimtinai visas pakrantės ruožas, einantis per visas keturias skirtingos vertès teritorijas, yra konversinè teritorija su dykrų, sandèlių, pramonès, infrastruktūros morfotipo atmainomis; ruožui reikalinga nauja urbanistinè koncepcija.

IV laipsnio vertès teritorija struktūriškai sudaro foną I, II ir III laipsnio verčių teritorijoms. Todèl formuojant šią dalị tikslinga vadovautis planiškumo principu, būdingu Klaipėdos miestui, ypač iš apžvalgos taškų nuo Kuršių nerijos, ir taip sustiprinti I, II ir III laipsnio verčių teritorijų urbanistinès struktūros kompozicinę raišką. Pietinèje ir rytinèje IV laipsnio vertès teritorijos dalyje rekomenduojama išlaikyti čia jau susiformavusị (5 aukštų) foninio aukščio lygi su Trinyčių ir Skulptūrų parkų inkliuzais, o aktyviuose ir visuomeninę funkciją turinčiuose mazguose, sutampančiuose su Klaipedos Senamiestị juosiančiomis fortifikacijomis, bei saugomu teritoriju prieigose siūloma kurti naujus vaizdo elementus, nekonkuruojančius su susiklosčiusia urbanistine morfostruktūra, bet ją papildančius. Šiaurinejje dalyje (Zandvèro teritorijoje) reikia didinti foninio aukščio horizontalumą (ir taip sumažinti sovietiniais metais pastatytų statinių vizualinị aktyvumą) išsaugant miesto vilų (2-3 aukštų su pavieniais želdynais) intarpus.

Taip pat atkreiptinas demesys $\mathfrak{i t ~ t a i , ~ k a d ~ K l a i p e ̀ d o s ~}$ urbanistinès morfostruktūros charakteris iš esmès yra gana tolygus aukštingumo požiūriu, nes miestas pernelyg nepasižymëjo kontrastinga vertikalių sankaupa, kaip tai būdinga, tarkim, Vilniaus Senamiesčiui. O dèl gretimų kvartalų aukštingumo ir teritorijos lygumo Klaipedos istorinio miesto panorama atsiveria tik nuo
Kuršių marių pusès. Tad galima teigti, kad tai yra vienintelis matomas senojo miesto fasadas.

Šiaurinès miesto dalys. Visoje šiaurineje miesto zonoje Klaipèdos miškas net žvelgiant iš skirtingų apžvalgos taškų yra viso miesto gamtinès morfostruktūros želdynų pagrindas. Tai Klaipèdos miestui teikia rekreacinę ir ekologinę pusiausvyrą urbanizuotos morfostruktūros kontekste. Antroji šiaurinès miesto zonos dalis dèl gamtinių ribų (Danès upès ir Klaipèdos miško) laikoma įvažiavimo ruožu į skirtingų miestovaizdžių tipų (kurių sąlyginès ribos nežymiai pradeda ryškèti) Klaipèdos miestą. Šiaurinị miestovaizdị rekomenduojama išlaikyti silpnai urbanizuotą, o ties pačiu įvažiavimu į Klaipedos miestą, kertant jo administracinę ribą, rekomenduojama formuoti pagrindinị strategini patekimą informacinemis ir reklaminèmis vaizdinèmis priemonèmis. Centriniame miestovaizdyje rekomenduojama išlaikyti 2 aukštų foninị aukšti sudarant daugiaplaniškumą tiek nuo A1 kategorijos kelio Palanga-Šilutè, tiek nuo įvažiavimo ị Klaipèdą, nes dèl lygaus Klaipèdos reljefo ir užstatymo intensyvumo, artėjant link miesto centrinès dalies, ryškejja pietinis miestovaizdis. Pastarasis atitinka centrinès dalies buferinę zoną, o pagal lokaciją šiandieninis jos užstatymo intensyvumas nèra pateisinamas, todèl turi nemažai plètros ir didelių užstatymo aukštinimo rezervų. Tokia teritorijų diferenciacija pasiteisintų ir tolygaus reljefo atžvilgiu. Rekomenduojama konvertuoti apleistas infrastruktūros ir pramonines teritorijas ị naujos paskirties aplinką, o aktyvias ịvažiavimų atkarpas tiek $\mathfrak{i}$ Liepu gatvę, tiek i $\mathrm{H}$. Manto, akcentuoti aukštybiniais pastatais ir ịvaizdžio (pirmo ir antro) vidinio užstatymo mazgais.

Rytinès miesto dalys. Rytinę miesto zoną sudaro skirtingo charakterio ir plètros galimybiu miestovaizdžiai, taip pat skiriasi jų foninis aukštingumas. Pirmos dalies (ribojamos Danés upès) miestovaizdžiuose rekomenduojama neviršyti 2 aukštu foninio aukščio ir taip išsaugoti miesto daugiaplaniškumą, nes nuo kelio Palanga-Šilutè atsiveria miesto centrinès dalies miestovaizdis bei už jo esantys kranai su fone esančiais Smiltynès želdynais. Antroji dalis pagal nevienodas teritorijos plètros galimybes skirstoma ị kelis miestovaizdžius, kurių foninis aukštis nèra vienodas: šiauriniame rekomenduojama neviršyti 4 aukštų foninio aukščio, sudarant galimybę silueto daugiaplaniškumui (matomi gyvenamieji rajonai, kurių pastatų aukščio charakteris dinamiškas), o pietiniame - neviršyti 2 aukštų foninio aukščio. Visoje rytinejje mesto zonoje išskirtinėmis teritorijomis laikomi įvažiavimai ị Klaipedą - tai Vilniaus, Kauno kryptys ir Šilutès kryptis, tačiau šie 


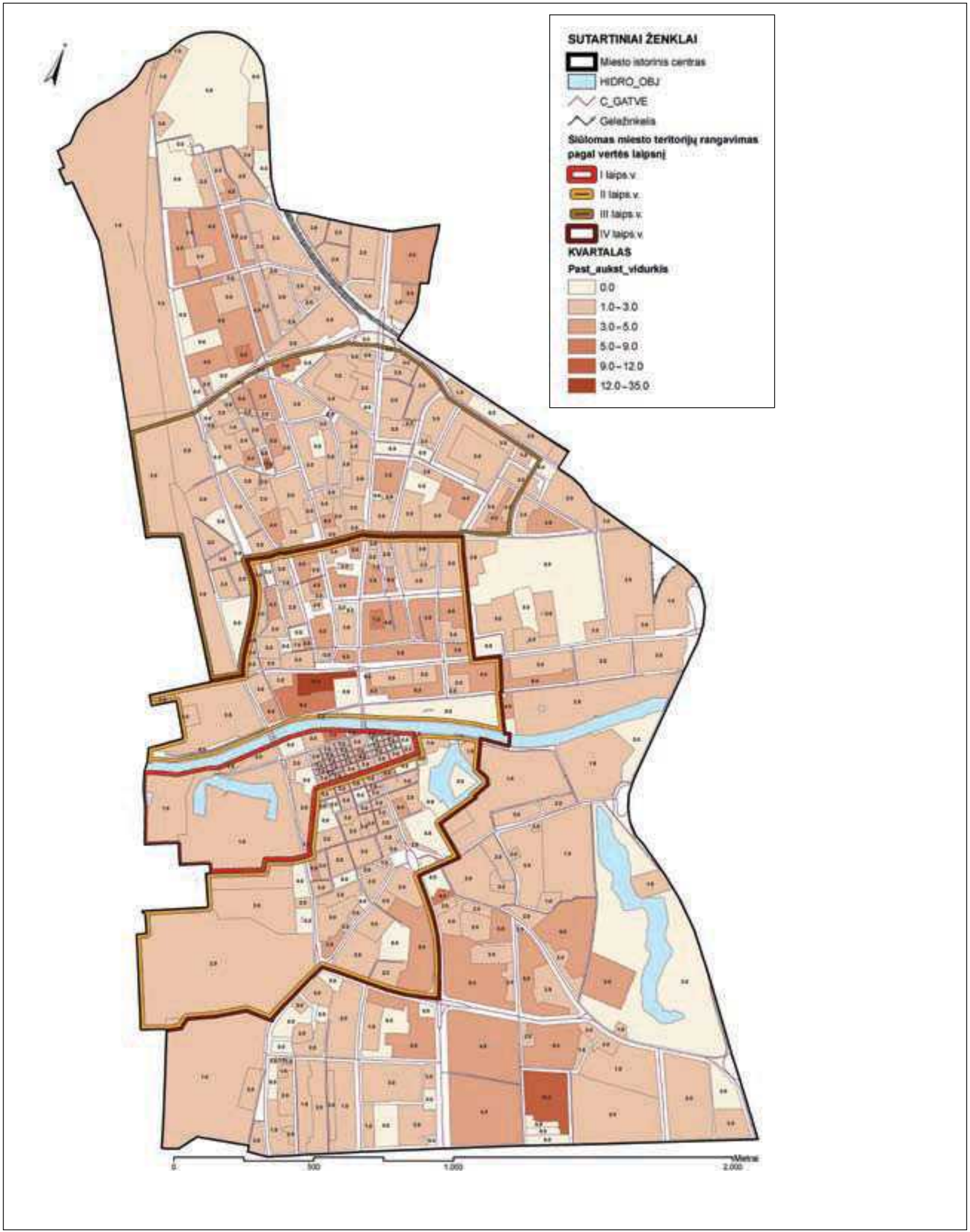

A

8 pav. Kvartalų maksimalus užstatymo foninis aukštis miesto centrinejje dalyje ( $M C D)$ : A - esamas, $B$ - perspektyvinis Fig. 8. Maximum buildup height of blocks in the central part of the city: A - existing type, $B$ - perspective type 


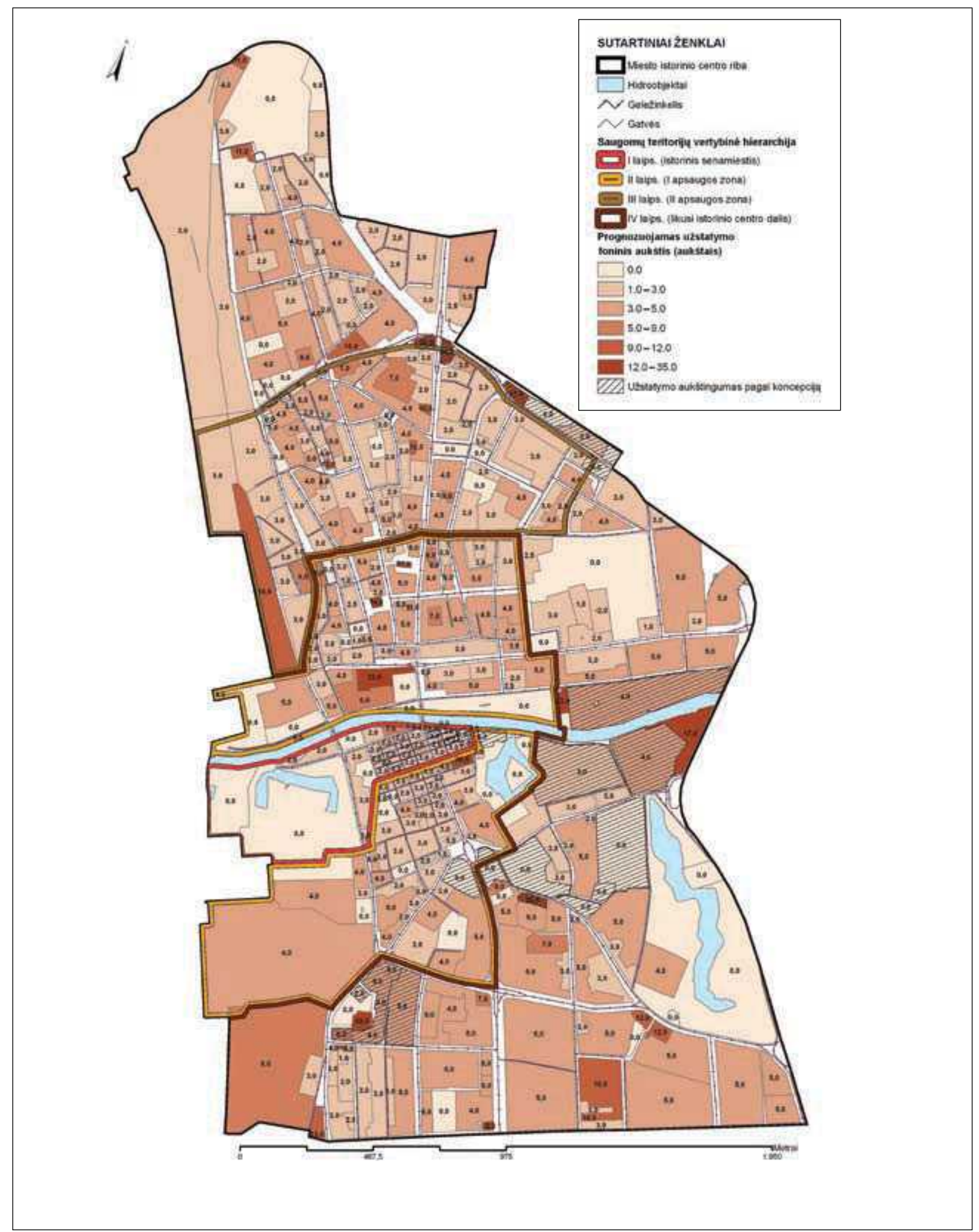




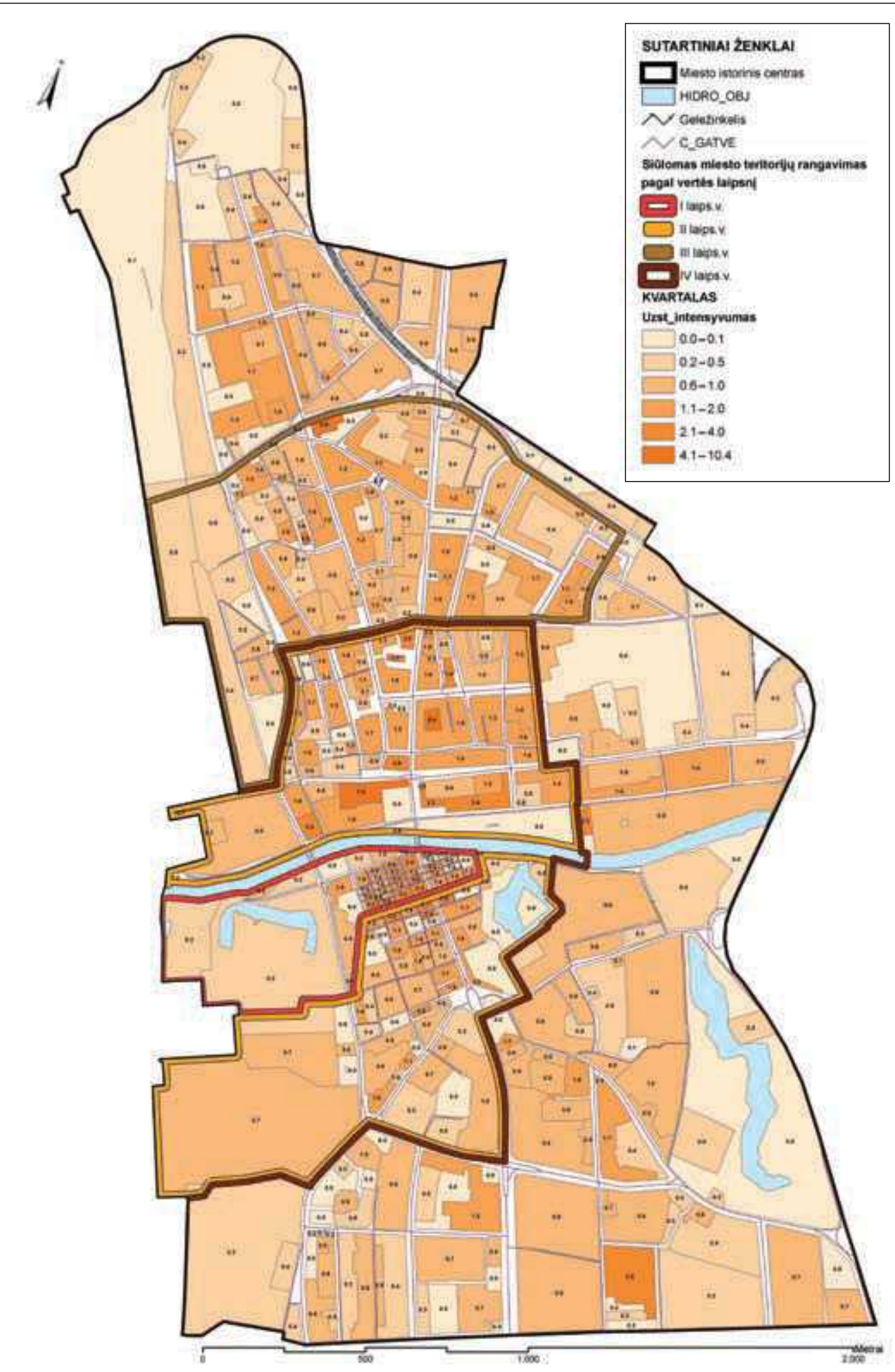

A

9 pav. Kvartalų maksimalus užstatymo intensyvumas miesto centrineje dalyje (MCD): A - esamas, B - perspektyvinis Fig. 9. Maximum buildup intensity of blocks in the central part of the city: A - existing type, B - perspective type 


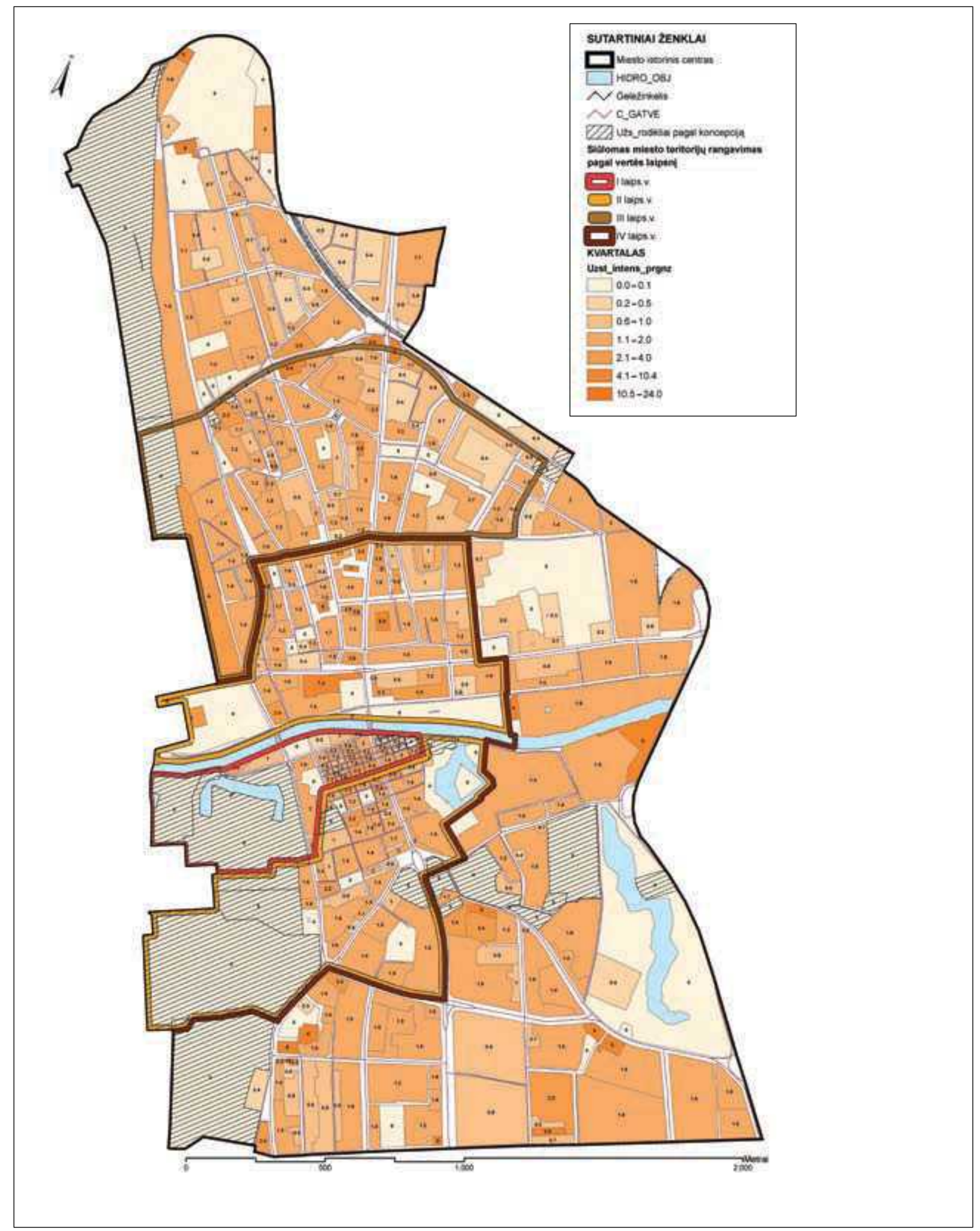




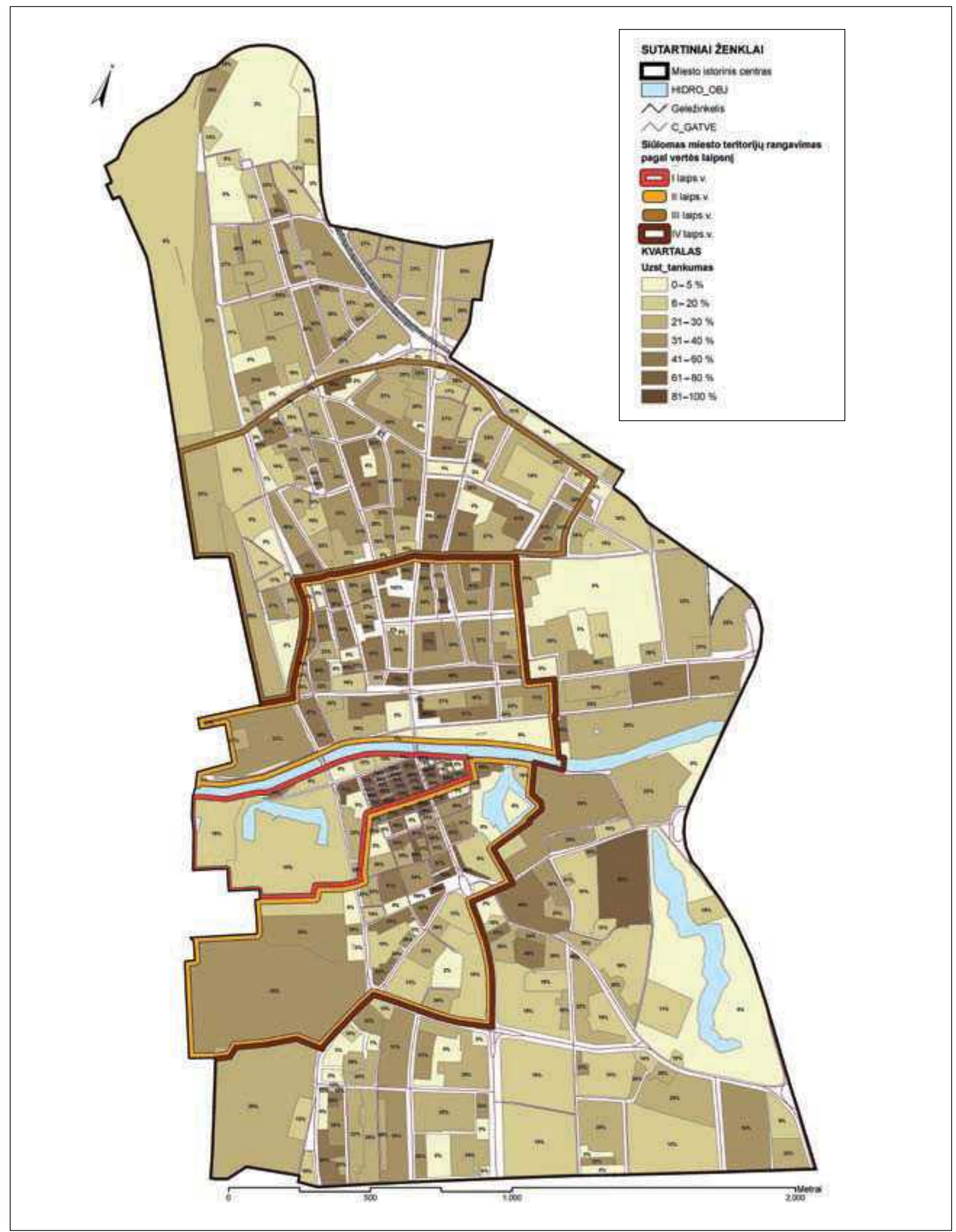

A

10 pav. Kvartalų maksimalus užstatymo tankumas miesto centrinejje dalyje (MCD): $A$ - esamas, $B$ - perspektyvinis Fig. 10. Maximum buildup density of blocks in the central part of the city: $A$ - existing type, $B$ - perspective type 


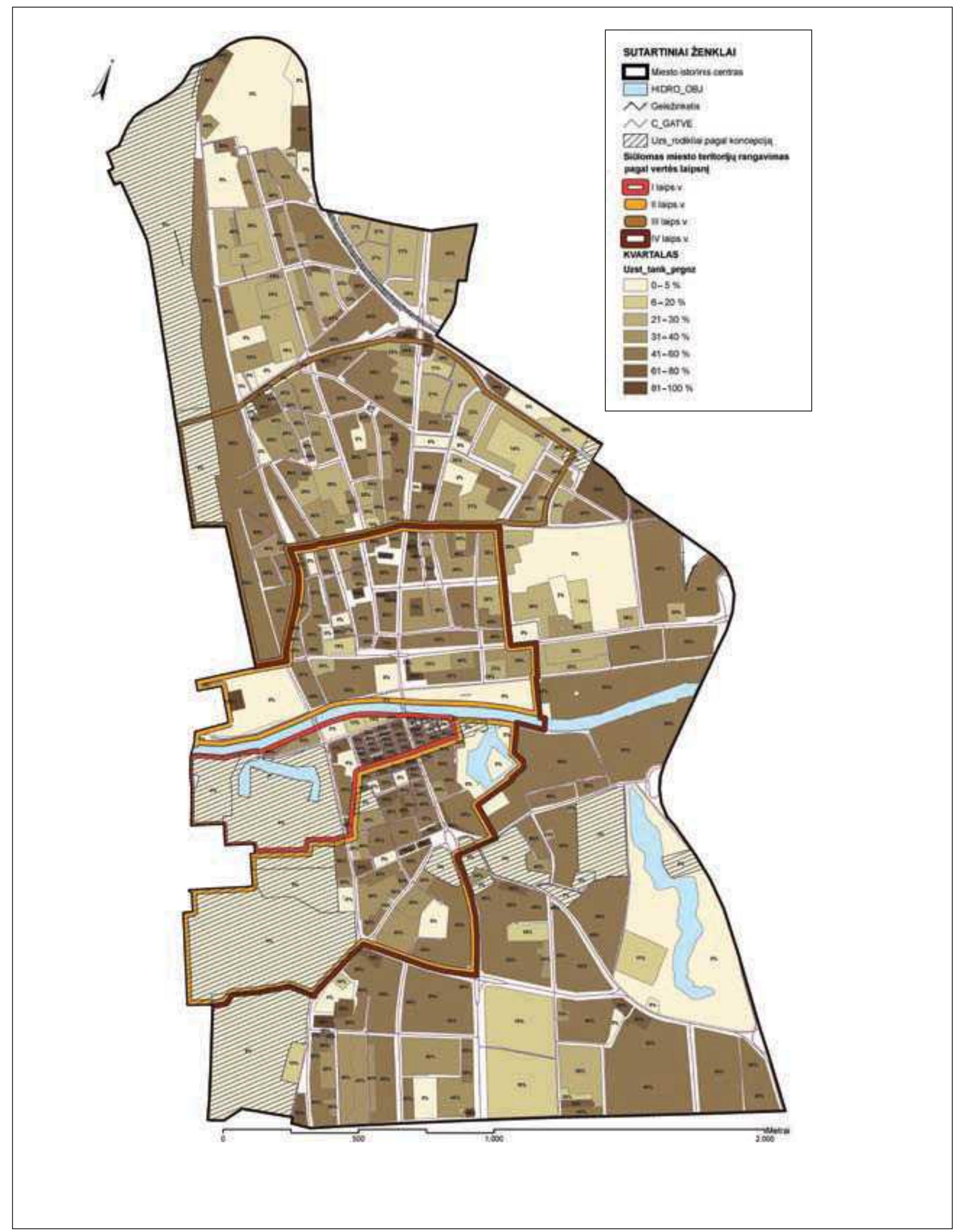


mazgai turi būti ženklinami skirtingos vizualinès informacijos perdavimo priemonemis. Patekimo teritorija ị Klaipèdą iš rytų svarbi visoje miesto morfostruktūroje, todèl jos užstatymo išraiška ir aukštingumo išryškinimas leistų įtvirtinti svarbaus miesto mazgo ìvaizdžio statusą. Siūloma miesto vartų idèja.

Pietinès miesto dalys. Sovietiniais metais miestą plečiant i pietus ši miesto zona su daugiaaukščiu gyvenamųjų namų rajonais sudaro stiprų kontrastą silpnai urbanizuotai šiaurinei miesto zonai. Baltijos pr. yra kompoziciškai svarus ir reikšmingas miesto elementas tiek funkcinès, tiek ir fizinès struktūros atžvilgiu. Todèl dèl pradètų investicinių projektų tokių kaip Gandrališkių kvartalas, pavienių aukštesnių statinių, atsiradusių nepriklausomybès metais, jau suderintų detaliųjų planų aukštybiniams pastatams statyti (nesant aukštybinių pastatų išdèstymo plano) bei sutelktų 9 aukštų pastatų (atkarpomis formuojančių prospekto perimetrą), Baltijos pr., kaip dominuojančio vizualinio koridoriaus atkarpoje, numatoma pagrindinè aukštybinių pastatų koncentracijos zona. Ateityje kompoziciškai pasiteisintų šios gatvės ašyje galimybè atsirasti perkèlai ị Smiltynę, nes dabartinè II perkèlos lokacija nèra patogi nei vietinių, nei atvykstančiųjų atžvilgiu. Tai galètų būti prielaida chaotiškai pėsčiųjų ir automobilių perkèlimo sistemai reorganizuoti. Aukštybinių pastatų koncentracija Baltijos pr. padètų išvengti investicijų koncentracijos vien tik ị centrinę miesto dalį. Pastatų aukštingumas gali siekti iki 100-120 m.

Dèl gana tolygaus gyvenamųjų rajonų charakterio rekomenduojama akcentuoti pagrindines išilgines gatves Taikos pr. ir Šilutès plentą bei jas jungiančių skersinių gatvių mazgus. Abi gatvès kompoziciškai aktyvios, tačiau nèra tarpusavyje lygiavertès: Taikos pr. viena aktyviausių miesto gatvių - tai Liepojos, H. Manto, Tiltų gatvių tęsinys (ji yra aptarnaujanti, miestiečių poreikius tenkinanti gatvè); Šilutès plentas yra apvažiuojamoji miesto gatve, iš dalies atliekanti ribos vaidmenị tarp gyvenamųjų ir pramonès teritorijų. Dèl to rekomenduojama formuoti skirtingo vizualinio charakterio atkarpas: Taikos pr. koncentruoti miestiečių poreikius atitinkančias funkcijas bei akcentuoti sankirtos mazgus su skersinėmis gatvėmis, o Šilutès plentą akcentuoti didesnio užstatymo tankumo neaukštybiniais pastatais. Visos šios dalies teritorijoje skersinių gatvių ašyse rekomenduojama formuoti prieigas prie Kuršiu marių. Ilgainiui tai ne tik paįvairintų Klaipėdos miesto morfostruktūrą, bet taptų jos tobulinimo veiksniu.

Beveik visi gyvenamujų mikrorajonų socialinès infrastruktūros objektai, tokie kaip vaikų darželiai, mokyklos, yra išdėstyti vienoje ašyje. Aplink šiuos objektus gausu nepanaudotų teritorijų, todèl jas panaudojant rekomenduojama formuoti aši kaip žaliąji pleištą ir taip kurti rekreacinę zoną. Ši būtų organizuojanti viešoji erdvè visiems mikrorajonams, $i$ bendrą kompoziciją įtraukiant piečiau esančias teritorijas. Ši sistema jungtų viešąsias erdves, žaliąsias zonas, pèsčiųjų, dviračių takus, kultūrinius, visuomeninius statinius ir jų kompleksus, aukštingumo požiūriu sudarytų oazę tarp gyvenamųjų rajonų.

Vakarinès miesto dalys. Vakarineje miesto dalyje kuriami keli skirtingo charakterio miestovaizdžiai. Smiltyneje dominuojančių želdynų charakteris turi būti išsaugotas, o ji keisti griežtai draudžiama, nes tiek Smiltyne, tiek Klaipedos miškas yra želdynų pagrindas visoje Klaipèdoje. Kur ne kur ịsiterpę ar susiformavę pavieniai sklypai, vertingi rekreaciniu požiūriu, turi nedideles užstatymo aukštinimo galimybes (Jūrų muziejus, etnografinè žvejo sodyba, Kuršių nerijos gamtos muziejus, jachtklubas). Čia yra pats aukščiausias Klaipedos gamtinis apžvalgos taškas ,iš išorès ị vidų“tai Hageno kalnas.

Pajūrio dalyje dominuojančios atskiros gyvenvietès, ịsiterpusios ị Klaipedos miško masyvą, kurio foninis aukštis 2-3 aukštų, taip pat turi būti išlaikytos. Siekiant išsaugoti želdynų dominavimą Klaipèdos panoramose (tiek nuo Baltijos jūros, tiek ir nuo plento Palanga-Šilutè) draudžiamas didelio aukštingumo užstatymas. Tik strategiškai svarbesnėse vietose galimas nežymus esamo užstatymo paaukštinimas vienu aukštu. Teritorijoje ties ịplaukimu į miestą rekomenduojama pramoninès teritorijos regeneracija, kuria remiantis Kuršių marių pakrantès grąžinamos visuomenei, îrengiant čia viešąsias erdves. Kadangi konversijos teritorijos turi dideli potencialą aukštybiniams pastatams atsirasti, būtinas jo galimos įtakos miesto siluetui ivvertinimas. Jūros vartus reikia projektuoti kaip dominantę miesto planineje struktūroje, dèmesị skiriant istorinių objektų - švyturio, Kopgalio saugojimui. Rekomenduojama atkurti istorinị kelią, jungiantị miesto centrinę dalị su Pajūrio dalimi.

Daugelyje Klaipėdos vietų didinti aukštingumą nerekomenduojama, nes dar nèra pakankamai ịsisavintos teritorijos užstatymo tankumo atžvilgiu, t. y. dalis užstatymo dar nèra pasiekusi savo ribinio tankio ir turi nemažai plètros rezervų.

Atliekant aukštybinių pastatų išdėstymo specialiojo plano koncepcijos sprendinius akivaizdu, kad be vertingų teritorijų nustatymo, morfotipų atpažinimo, užstatymo rodiklių identifikavimo sunku prognozuoti 
ne tik užstatymo aukštinimo perspektyvas, bet nusakyti plètros priemones ar apribojimus, kurie užtikrintų gamtos, kultūros vertybių ir vertingų miestovaizdžių išsaugojimą.

\subsubsection{Aukštybinès statybos plètojimo miesto urbanistinèje struktūroje konkretizavimas}

Miesto teritorijos turi skirtingas modernizavimo ir aukštybinių pastatų santalkos bei pavienių pastatų lokalizavimo galimybes ir reikmę. Pastaroji tarsi ir nulemta aukštybinių pastatų išdèstymo kompoziciniame modelyje, o lokalizavimo galimybès bei principai, aptarti atsižvelgiant ị morfotipus, šiame skirsnyje atskleidžiami konkrečiau.

Aukštybinès statybos plètojimo miesto urbanistinejje struktūroje konkretizavimas priklauso nuo vertikalès galimybès kiekvieno miestovaizdžio identifikuotame morfotipe:

- vertikalès statymo galimybè: 1) leidžiamos; 2) neleidžiamos; 3) vertikalių reikmè priklauso nuo urbanistinès koncepcijos;

- vertikalès statymo būdas: 1) vertikalé, atskirai stovinti bendroje erdvejje; 2) vertikalè stovinti kvartalo viduje, 3) vertikalèmis formuojama grupè, 4) vertikalemis formuojama linija;

- maksimalus vertikalès santykis su foniniu aukščiu;

- vertikalès proporcijos (viršūnès modeliavimas);

- vertikalès aukštis (aukštais);

- vertikalès aukštis (metrais).

Aukštybinèstatyba, kaip ir miestovaizdžiųišsidèstymas, yra teritoriškai diferencijuota ir griežtai reglamentuota. Tai akivaizdu peržvelgus visas pagal kompozicinius kriterijus išskirtas teritorijas. Čia pateikiamos tik bendrinès rekomendacijos (susijusios su kompoziciškai svarbiomis ir aktyviomis teritorijomis) aukštybinei statybai plètoti Klaipèdos morfostruktūroje:

- Siluetui

- Nustatyti specialieji reikalavimai miesto siluetui. Klaipedos siluetas miesto raidoje iki karo formavo grakštaus, išraiškingo miesto vaizdą. Pagrindiniai silueto formantai - laibi laivų stiebai, smailūs bažnyčių stogai, pilies bokštai ir gamtiniai elementai - žalieji plotai. Klaipèdos miesto siluetas gali būti praturtintas tik sekant daugiaplaniškumo principu, todèl miestovaizdžiai bei jų užstatymo aukštingumas turi būti diferencijuotas, nes esant tolygiam Klaipedos reljefui kai kurios vertingos miesto dalys, matomos iš konkrečių apžvalgos taškų, gali būti „nebematomos“ arba vizualiai „užterštos“ netinkamo aukštingumo užstatymu.

- Kadangi konversijos teritorijos turi dideli potencialą aukštybiniams pastatams atsirasti, būtinas jų galimos ịtakos miesto siluetui ịvertinimas (bendras miesto silueto vaizdas susidaro tik esant miestui šalia atviro jūros kranto).

- Miesto vartu samprata kinta priklausomai nuo atitinkamos funkcijos svarbos konkrečiu laikotarpiu. Jie buvo suvokiami kaip aiški riba, vèliau ji tapo menama, šiandien ją žymi stambūs kompleksai arba taškinès vertikalès. Tiek miesto vartu, tiek silueto sąvokos samprata siejama su miesto ivvaizdžio kūrimu, todèl tikslinga šiuos abu reiškinius tarpusavyje sieti, ịvertinant galimą miesto vartu ir jūros vartu ittaką miesto siluetui.

- Miestovaizdžiams

- Aukštybinių pastatų statyba draudžiama gamtiniu ir kultūros paveldo požiūriu svarbiose teritorijose bei jų apsaugos zonose.

- Pastatų aukštingumo apribojimus lemia miestovaizdžių charakteris bei silueto suvokimas iš nustatytų apžvalgos taškų. Identifikuotos vizualinès ribos jautriausiai ir pažeidžiamiausiai miesto teritorijai (nustatyta vizualinio identiteto riba tiek gamtinèje, tiek urbanizuotoje morfostruktūroje bei vizualinio dominavimo riba).

- Numatyta aukštybinių pastatų grupių ir visuomeninių erdvių sistema aplink Senamiestị padètų aiškiai identifikuoti Senamiesčio ribą ir išskirtų ji bend ro miesto kontekste, nes vertingiausia miesto dalis miesto dalių hierarchineje sistemoje turi užimti svarbiausią vietą.

- Aukštybiniais pastatais pabrèžiama vizualinị identitetą lemiančių struktūrinių miesto elementų hierarchija.

- Naujuose rajonuose tinkamiausios aukštybiniams pastatams zonos atsiranda reikšmingose miesto funkcinès ir fizinès struktūros vietose - ties magistralių mazgais, ịvažiavimais ị kompaktiškai užstatytą miesto centrinę dalị, jais pabrezžiamos ir pagrindinès miesto ašys, reprezentacinès ir magistralinès gatvès, pagrindiniai įvažiavimo it Klaipèdą keliai.

- Aukštybiniams statiniams

- Saugotinu technogeniniu elementu, išreiškiančiu miesto specifiką, atskiriant miestą nuo Baltijos jūros, laikomi kranai.

- Aukštybinès statybos mastas ir vietos bei vizualinis aktyvumas neturètų nustelbti šiaurinès ir vakarinès dalių miestovaizdžiuose vyraujančios 
gamtinès morfostruktūros vizualinio prioriteto. Pirmenybè turètų būti teikiama kultūriniam bei gamtiniam veiksniams.

- Palankesnès pavienių aukštybinių pastatų išdèstymo galimybès apleistose ir nutolusiose teritorijose nuo paveldosauginių teritorijų, mažiausios galimybès miesto centrinèje dalyje, didžiausios pietinejje miesto zonoje, kur planuojami Baltijos prospekte daugiaaukščiai suformuotų architektūrinę kalvą ir pabrèžtų pagrindinị kelią ị uostamiestị.

- Kadangi Klaipedos miestas yra lyguminis, siūloma aukštybinių pastatų statybą numatyti kuo toliau nuo kranto ir taip formuoti daugiaplani miesto vaizdą (11 pav.).

- Klaipeddos mieste vertikalios dominantès leidžiamos, jeigu:

a) neviršijami toje teritorijoje numatyto užstatymo ribiniai tankio ir intensyvumo rodikliai;

b) vertikali dominante priimtina urbanistiniu ir kompoziciniu aspektais, tiksli vertikalios dominantès riba apibrěžiama teritorijos (kvartalo) detaliajame plane;

c) išvengiama neigiamo poveikio panoramoms ir siluetui, žiūrint iš SP nurodytų miesto apžvalgos taškų;

d) nepažeidžiamos gretimų sklypų turtinės teisès, sanitarijos ir higienos sąlygos, gaisrinès saugos normos.

Zonose, kurioms reikalinga urbanistinè koncepcija ar i̇manoma aukštybinè statyba, specialiojo plano sprendiniai konkretizuojami atliekant urbanistinès plètros galimybių studijas, planavimo pasekmių vertinimą. Teritorijoms, kurioms iš esmès reikalinga nauja koncepcija, turètų būti skelbiami konkursai. Autorès nuomone, modernizuojamose ir konvertuojamose teritorijose (o tokių Klaipėdoje netrūksta) ne visada tikslinga imituoti praeities vertybes, reikia dažniau vadovautis senųjų vertybių respektavimu padedant naujai kontrastingai architektūrai remiantis naujomis idejjomis (ypač šiuo metu propaguojama ekologiškumo tendencija) . Iš esmès tai deklaruoja ir Venecijos chartija, kad kiekvienas laikotarpis privalo palikti savo žymę teritorijoje dèl miesto įvairovès bei vertybių evoliucijos užtikrinimo (Bučas 2006).

\subsection{Aukštybinių pastatų išdèstymo specialiojo plano rezultatai}

Reglamentuojant aukštybinès statybos plètrą bei apsaugant vertingiausias gamtiniu, istoriniu požiūriu miesto teritorijas buvo parengta ne vien aukštybinių pastatų išdèstymo schema/specialusis planas, bet ir viso miesto kvartalų užstatymo reglamentas. Jo nereikalavo nei užsakovas (t. y. Klaipèdos miesto savivaldybė), neprivalomas jis ir pagal galiojančias aukštybinių pastatų išdèstymo specialiųjų planų rengimo taisykles (Aukštybinių ... 2004). Tačiau be viso miesto kvartalų užstatymo plètros galimybių abejotinas tampa koncepcijoje nustatytų ir konkrečioje teritorijoje numatytų aukštybinių pastatų tikslingumas. Vadovaujantis viso miesto kvartalų užstatymo aukštingumo reglamentu akivaizdžios ir gretimų teritorijų aukštinimo galimybès, išvengiama netikslaus aukštybinių pastatų aiškinimo.

Iš surinktos, apdorotos ir parengtos informacijos buvo parengti trys aukštybinių pastatų išdèstymo specialiojo plano brěžinių variantai, kurių informacijos kiekis ir jos atvaizdavimas buvo skirtingas (12 pav.):

- pirmas - visos Klaipedos miesto administracinès teritorijos aukštingumo reglamentavimas pagal kompleksą rodiklių, nusakančių tos teritorijos plètrą. Aukštingumo reglamentas parengtas su lentelès formos priedu, kuriame aprašytas kiekvienas išskirtas struktūrinis vienetas (žr. lentelę). Toks detalus teritorijos ištyrimas ir maksimaliausių galimų užstatymo rodiklių reikšmių nustatymas palengvintų vykdyti teritorijos plètrą bei informacijos monitoringą (iki šiol daugelis savivaldybių nevykdo informacijos atnaujinimo politikos);

- antras - atvaizduotas tik maksimalus galimas foninio aukštingumo ir aukštybinių pastatų statymo principų reglamentavimas (be papildomų užstatymo rodiklių);

- trečias - išryškintos tik pastatų aukštingumo zonos, nenurodant gretimų teritorijų užstatymo galimybių aukštingumo aspektu.

Visuose brèžiniuose žymima miesto centrinis rajonas, miesto vizualinio identiteto zonos ir teritorijos, kuriose galima aukštybinès statybos plètra, su aukštybinių pastatų leistinais aukščių parametrais. Tiek pirmajame, tiek antrajame brèžiniuose teritorijos, net ir turinčios mažesnę įtaką miesto įvaizdžiui, yra detalizuotos.

Užsakovas rengiant specialųji planą atmete pirmąji, vèliau ir antrąji daug laiko ir pastangų pareikalavusị ìdirbį. Kaip jo rezultatas liko pagal aukštybinių pastatų išdèstymo specialiųjų planų rengimo taisykles išskirtos aukštybinių pastatų išdèstymo zonos ir teritorijos, kuriose draudžiama statyti tokius pastatus, o šių teiginių motyvacija liko „už kadro“. Be viso miesto užstatymo plètros galimybių specialusis planas tarsi 


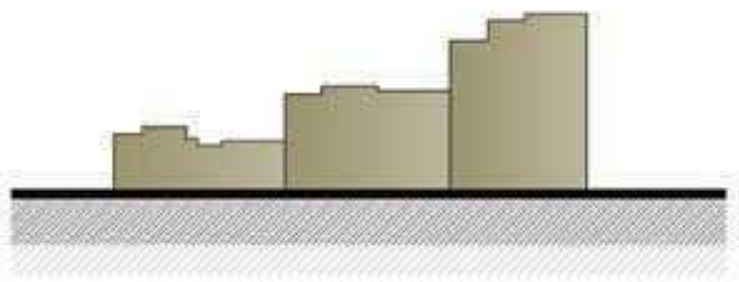

A

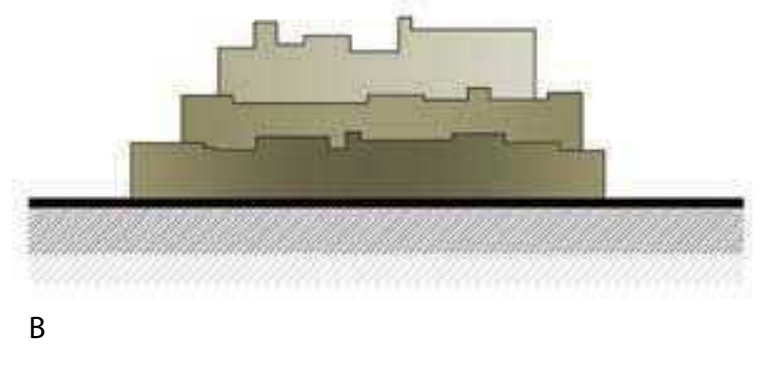

11 pav. Miesto silueto formavimo schemos: $A$ - kalvos principas, $B$ - daugiaplaniškumo principas

Fig. 11. Schemes of the city silhouette formation: $A$ - hill principle, $B$ - multi-plan principle

išmėtytų zonų kratinys. Pirmieji du brèžiniai ne tik neprieštaravo esminiam miesto erdvinès struktūros formavimui, bet pagal informacijos kiekị miesto plètrai yra dar svarbesni nei aukštybinių pastatų specialusis planas, nes, be zonų galimoms vertikalèms, nurodomi ir kompoziciniai miestovaizdžių formavimo principai: tai yra neatsiejama nuo Klaipèdos vizualinio įvaizdžio plètros galimybių.

Nors šie brèžiniai tarpusavyje susiję, tačiau informacijos kiekis juose nevienodas. Aukštybinès statybos formuojamos urbanistinès morfostruktūros plètojimo galimybės grindžiamos koncentruotu linijiniu vertikaliu dominančių išdèstymu semantizuojant miesto urbanistinę struktūrą. Tai atitinka Klaipèdos morfostruktūros charakteri - linijinis miestas, kurio topografija pasyvi. Aukštybinių pastatų išdèstymas susijęs su centrinių gatvių ir kompozicinių branduolių išryškinimu.

\section{Aukštybinių pastatų išdèstymo sprendinių poveikio vertinimas}

Lietuvos patirtis rengiant tokius planus yra labai menka, todèl jie gana sunkiai įvertinami ir pripažistami ne tik juridiškai, bet ir tarp specialistų dèl galutinès savo veikimo ir galiojimo patikros. Kas ir kokiais principais vertins iniciatyvas statyti aukštybinius pastatus po to, kai bus patvirtintas aukštybinių pastatų išdėstymo specialusis planas? Kontrolés mechanizmą galetuc vykdyti savivaldybės sudaryta moksliniais pagrindais besiremianti pastovi ir nepriklausoma struktūra, vykdanti monitoringą moksliniais metodais

Aukštybinių pastatų išdèstymo sprendinių poveikio vertinimas atliekamas:

- miesto vizualiniam ịvaizdžiui;

- strateginių pasekmių aplinkai.
Pastarasis vertinimas buvo atliekamas kitų kompetentingų specialistų, kurių išsakyti pastebejjimai neprieštaravo specialiojo plano derinimo eigai, todèl šiame straipsnyje išsamiau neaptariami.

\section{Aukštybinių pastatų išdèstymo plano sprendinių poveikio miesto vizualiniam ịvaizdžiui vertinimas}

Didejjantis pastatų bei statinių aukštingumas ir ypač naujo tipo statinių atsiradimas (daugiaaukščiai biurai, gyvenamieji, inžineriniai statiniai ir kt.) kelia realų pavojų jau susiformavusiam miestovaizdžiui, nes miestovaizdis, miesto siluetas ar jo panoramos gali iš esmès pasikeisti per labai trumpą laikotarpí. Aukštybinių pastatų išdèstymo plano sprendinių poveikio vizualiniam įvaizdžiui vertinimas atliekamas:

- stebint iš nustatytų masinès apžvalgos taškų;

- nustatant poveiki bendram miesto silueto ir panoramų pokyčiui.

Abu šie punktai susiję su vienu svarbiausių miesto vizualinio identiteto charakteristiku - siluetu. Dèl jo svarbos miesto morfostruktūroje nekyla diskusijų:

- tai urbanistinès struktūros komponentas (kurio savybès vertintos kaip urbanistinès struktūros indikatoriai) (Bučas 1995);

- riba tarp miesto kūno ir beribio dangaus (Гутнов ... 1990);

- tolimas kontūrinis užstatymo ar gamtinių elementų vaizdas dangaus skliauto fone (Aukštybinių ... 2004).

Iki Antrojo pasaulinio karo miesto siluete dominuojantys pastatai buvo svarbūs savo funkcine reikšme (13 pav.). Išaugus technologinèms galimybèms didejjo gyvenamų namų, visuomeninių, kultūrinių ir kitų statinių aukštingumas. Tokiu atveju nekelia nuostabos 


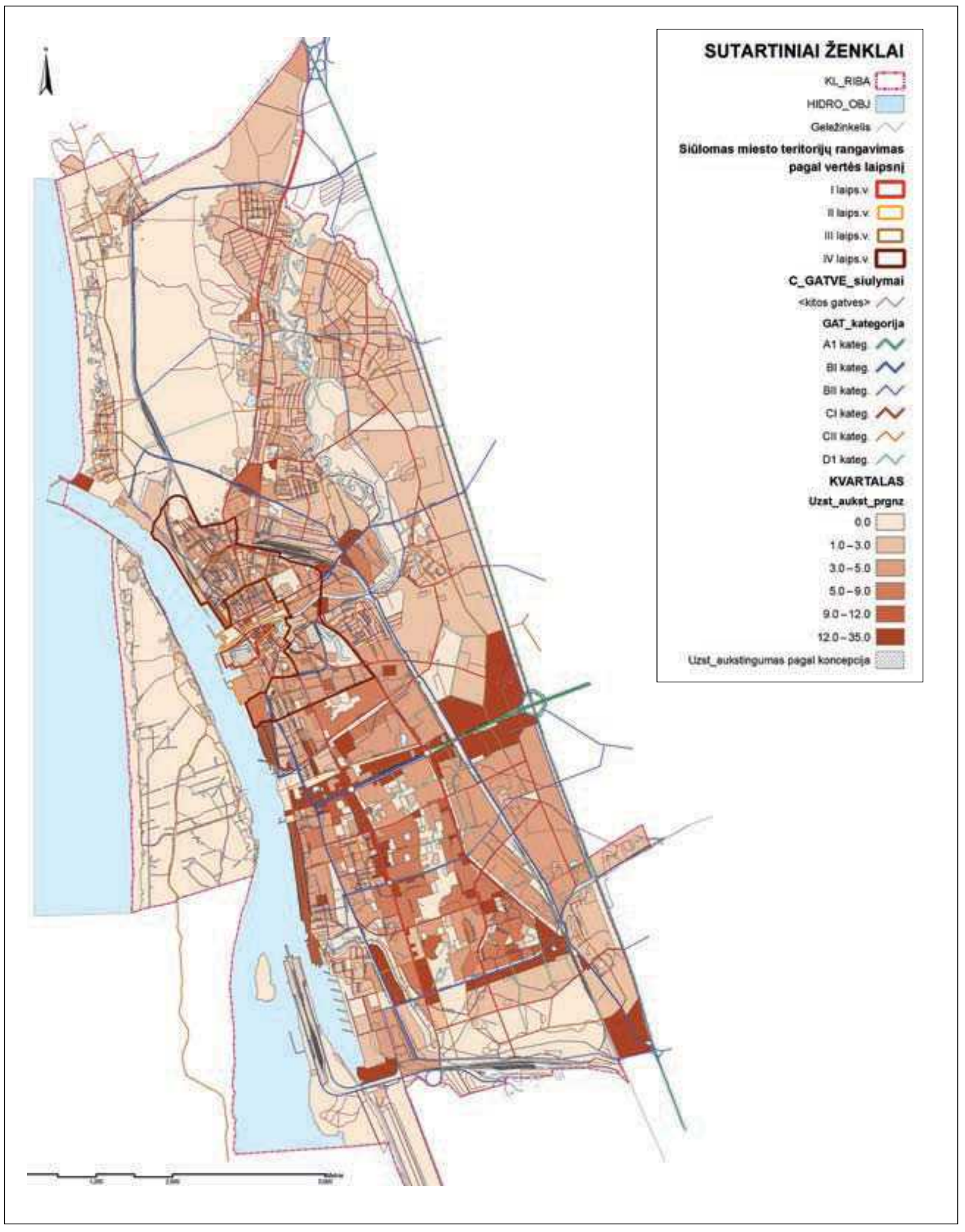

1

12. pav. Klaipėdos miesto aukštybinių pastatų išdėstymo brèžinių variantai

Fig. 12. Versions of schemes of high-rise building arrangement in Klaipeda city 


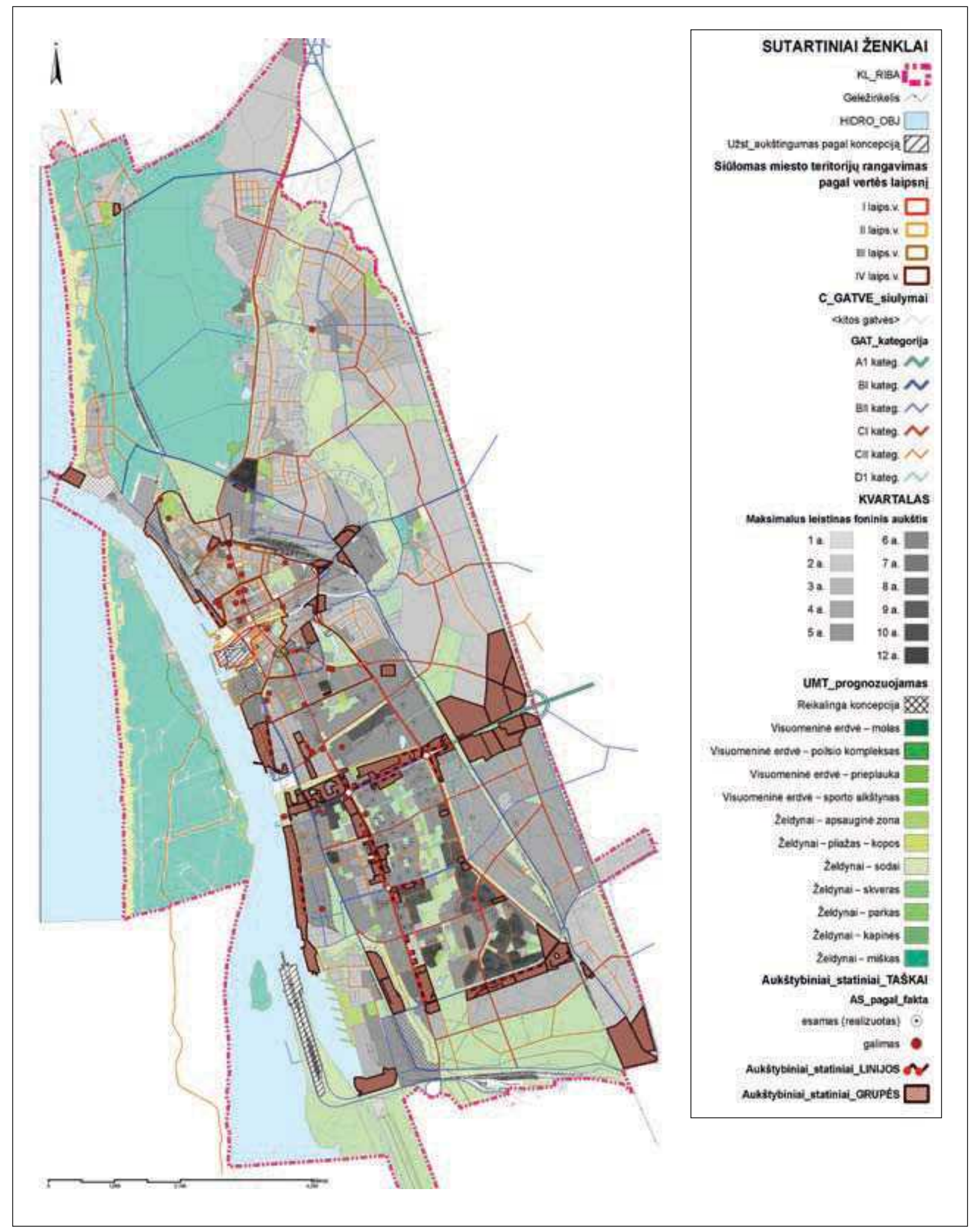




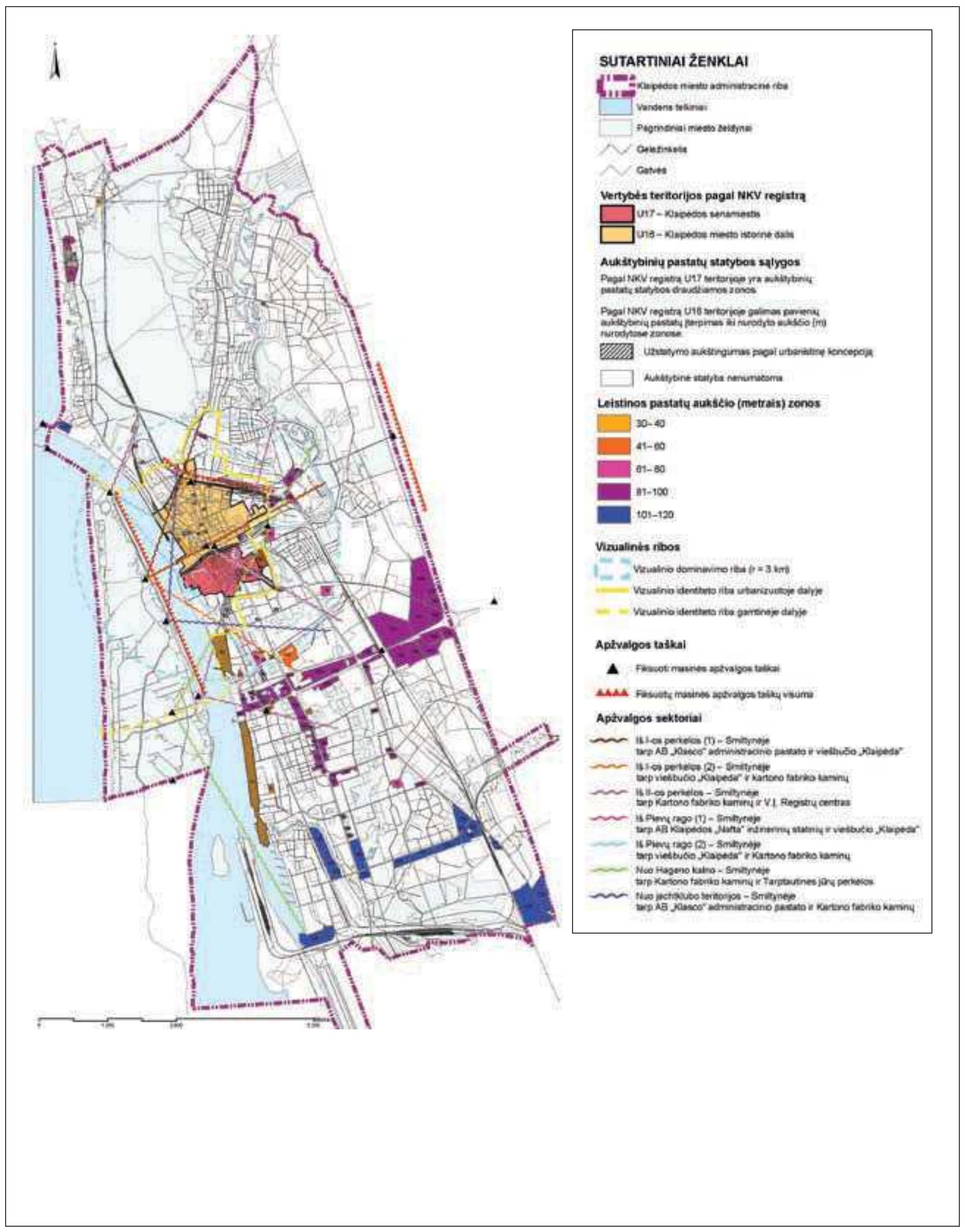




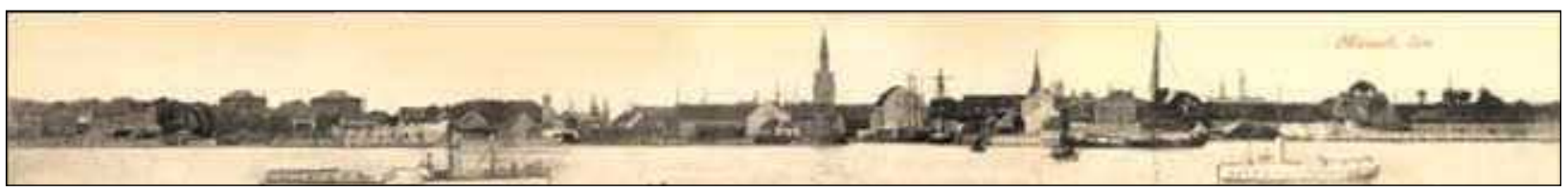

13 pav. Klaipèdos miesto siluetas $1902 \mathrm{~m}$.

Fig. 13. Silhouette of Klaipeda city in 1902

miesto siluete proporcingai didèjančio dominuojančių pastatų aukštingumo poreikis. Tačiau tai kelia grèsmę istorinio miesto siluetui. Todèl projektuojant naujus aukštybinius pastatus Klaipedos mieste, jų itaka miesto siluetui ir panoramoms vertinama atliekant vizualinio poveikio studijas, kurios reikalingos:

- kaskart, kai rengiamas detalusis planas, kuriame planuojami aukštybiniai pastatai ir net pastatai, viršijantys miestovaizdžio nustatytą foninị aukštị, ypač kultūrinę vertę turinčiose teritorijose ir jų apsaugos bei vizualinès apsaugos zonose;

- planuojamų aukštybinių pastatų patikra ir vertinimas turi būti atliekami nepriklausomai, kuriame miestovaizdyje ir ar vertingose, ar mažesnę vertę turinčiose teritorijose jie projektuojami;

- vertinimas vyksta iš nustatytų apžvalgos taškų.

Nebaigti rengti arba netinkamai parengti aukštybinès statybos DP turètų atitikti Klaipedos miesto savivaldybès tarybos patvirtinto Aukštybinių pastatų išdèstymo specialiojo plano teiginius.

Vizualinio poveikio studijoje turi būti:

- vizualinių pasekmių tyrimas atliekamas GIS technologijomis, parengus schemą, kurioje nustatytos teritorijos, iš kurių matosi naujai planuojamas pastatas;

- parengiami trimačio miesto modelio vaizdai iš nustatytų miesto apžvalgos taškų su naujai planuojamu pastatu.

SP padeda kontroliuoti atskirų stambesnių objektų ¡̇komponavimo ị miesto urbanistinị kontekstą eigą, taip pat nustatyti tokių objektų poveikị vizualiniam identitetui. Vizualiniu pasekmių tyrimas nèra laikomas tinkamu, jeigu komentuojamos pasekmès vizualiniame kadre, įmontavus objektą taikant architektūrinès grafikos programas (PhotoShop, CorelDraw ir pan.). Šis būdas yra plačiai paplitęs tarp architektų, tačiau yra labai subjektyvus ir priklauso nuo daugelio veiksnių (objekto autoriai dažnai daro labai dideles paklaidas, be to, nèra aišku, kas ir kaip ,imontuoja “ i esamą vaizdą planuojamą pastatą ir pan.). Planuojamų pastatų pasekmių neturètų vertinti patys autoriai.
Ankstesnius detaliuosius planus siūloma vertinti pagal tokius kriterijus:

- visi aukštybiniai pastatai, pastatyti iki šio plano patvirtinimo, ko gero, funkcionuos nepriklausomai nuo to, kokios vertės teritorijose yra pastatyti, todèl pastatus, neatitinkančius šio specialiojo plano sprendinių, ateityje rekomenduojama rekonstruoti;

- pateikiama medžiaga turi būti išsami ir konkreti, reikia nustatyti, ar:

- patvirtintas DP turi privalomas dalis ir tikslius reglamentus;

- patvirtintas DP leidžia prognozuoti architektūrines pasekmes miesto įvaizdžiui ir istoriniam kontekstui;

- patvirtintas DP paremtas teritorijos (ne tik sklypo) plètros galimybių studijomis, nes DP nèra vien formali juridinè procedūra, îteisinanti bet kokią statybą;

- patvirtintame DP nurodyti reglamentai yra pagrịsti ir realūs, t. y., ar DP reglamentai ịrodomi projektiniais pasiūlymais, skaičiavimais, pasekmių tyrimais ir pan.

Tai, kad numatytose vietose būtų statomos vertikales, toliau reglamentuojama ir tikslinama nebe Aukštybinių pastatų išdėstymo specialiajame plane, o detaliuosiuose planuose, kuriuose turètų būti nurodoma ne tik aukščiausia riba, bet ir minimalus privalomas pastato aukštis. Rengiant detaliuosius planus gali būti ivvertinamas užstatymo morfotipo kitimas ir konversija. Šie pakitimai gali būti (Klaipèdos ... 2007):

- jei tai yra numatyta galiojančiuose planavimo dokumentuose;

- atlikus išsamią esamos padèties analizę ir nustačius, kad planuojamoje teritorijoje vyraujantis užstatymas neatitinka užimamos mieste teritorijos statuso;

- esamas užstatymas neturi išliekamos vertès ir privalo būti keičiamas kitu, intensyvesnị teritorijos panaudojimą leidžiančiu morfotipu.

Realizuojant aukštybinių pastatų išdèstymo specialiojo plano sprendinius tikimasi, kad bus sukurta kokybiškesnè tiek viso miesto, tiek atskirų jo dalių aplinka. 


\section{Išvados}

1.Pasaulinè miestų plètros tendencija - hierarchizuoti miestovaizdžius rūpinantis vizualinio įvaizdžio ir identiteto stiprinimu. Tai iš esmès mažina niveliuojančią globalizacijos įtaką miestų struktūroms. Klaipèdos atveju miestovaizdžių hierarchizavimas kompozicinèmis priemonemis užtikrina miesto struktūros tobulèjimą ir pateisina kompozicinès plètros idejąa.

2.Sprendinių konkretizavimo etape subalansavus tokius struktūrų parametrus kaip tolygi aukštingumo kaita, urbanistinis reljefiškumas, priderintas prie aplinkos, mastelis, atskirų zonų tarpusavio vizualinis ir funkcinis ryšys, visuomeninio intereso tenkinimo mastas, sukuriamas apibendrintas, ilgalaikis urbanistinis struktūrinis modelis Klaipèdos miesto vizualiniam identitetui išsaugoti bei stiprinti, kartu užtikrinama jo kryptinga plètra.

3. Daugelyje vietų išskirti struktūrinių dalių miestovaizdžiai nèra vienalyčiai ir kompoziciškai užbaigti. Dideli plètros rezervai užslèpti kiekvienoje teritorijoje. Didžiojoje dalyje kvartalų (visose struktūriškai išskirtose miesto dalyse) yra tendencija tobulinti užstatymo morfotipą užstatymo rodikliais.

4. Nustačius užstatymo rodiklių ribines galimybes kiekviename morfotipe, išryškejo teritorijos užstatymo tankinimo potencialas net nekeliant užstatymo aukštingumo. Taigi užstatymo perspektyvinis foninis aukštingumas beveik nesikeičia arba kinta labai nežymiai, išskyrus strateginèse ir miesto kompozicinio karkaso požiūriu svarbiose teritorijose, kurių akcentavimas didesnio aukštingumo pastatais paịvairintų dabar gana monotonišką miesto siluetą. Rodikliams viršijus nustatytas reikšmes, reiktų tokio peržengimo urbanistinio pagrindimo ir pasekmių ịvertinimo.

5. Klaipedos mieste yra didelès investicinès galimybès, bet joms realizuoti reikalingos įvairios studijos. Ypač teritorijose, reikalaujančiose naujų koncepcijų, nes reikia peržiūrèti jų potencialą ir ịvertinti plètros galimybes. Miesto savivaldybė nepajègi finansuoti panašiu projektų rengimo, todèl turètų efektyviau išnaudoti investuotoju galimybes finansuoti ịvairaus rango mokslinius tyrimus, studijas, analizes ir pan. Tokio masto problemoms spręsti nepakanka investuotojo finansuojamų atskirų objektų architektūrinių konkursų. Kultūros paveldo ir gamtos vertybių apsaugai miesto ekonominè sèkmè taip pat būtina.

6. Miesto užstatymo aukštingumas su aukštybinių pastatų išdèstymu nustatytas kompleksiškai, vadovaujantis vyraujančio miestovaizdžio tipu ir jam būdingais užstatymo tipais bei jų užstatymo rodiklių visuma.
Ši informacija itin palengvintų detaliụjų planų rengimą.

7.Šis specialusis planas dar kartą patvirtino būtiną pusiausvyrą tarp visuomeninių ir privačių interesų, skatinančių tobulèti miestovaizdžius. Urbanistinès analizès mokslo laboratorijos parengtas aukštingumo reglamentas - ne tik aukštybinių pastatų išdèstymo schema, bet ir sisteminis vadovas, apimantis kompozicinius miestovaizdžių formavimo principus. Deja, patvirtinta aukštybinių pastatų išdèstymo versija su pavaizduotomis aukštybinių pastatų zonomis ir teritorijomis, kuriose draudžiama statyti tokius pastatus.

8. Viena pagrindinių aukštybinių pastatų išdèstymo schemos/specialiojo plano sèkmingo funkcionavimo ir realizavimo prielaidu yra ta, kad specialusis planas turi veikti teritorijų planavimo dokumentų ir plètros galimybių studijų sistemoje. Aiškiai apibrěžiant vertingo vaizdo kitimo sąlygas, kartu būtų vykdomas specialiojo plano realizavimo monitoringas, kuris Lietuvos savivaldybėse vykdomas vangiai.

\section{Literatūra}

Alistratovaitè, I. 2004. Morfologinès struktūros transformacijos centriniame miesto rajone (Lietuvos pavyzdžiu): daktaro disertacija (humanitariniai mokslai, menotyra). Vilnius. $242 \mathrm{p}$.

Alistratovaitè, I. 2008. Uostamiesčio vizualinio įvaizdžio formavimo galimybès ir problemos: aukštybinių pastatų specialiojo plano rengimas - esama situacija ir koncepcija, Urbanistika ir architektūra 32(2): 71-85.

Aukštybinių pastatų išdèstymo specialiųų planų rengimo taisyklès. LR 2004 m. gegužès 5 d. ịsakymu Nr. D1-246. 2004 m. gegužès 13 d., Valstybès žinios 79: 74-78.

Bučas, J. 2006. Demokratiniai proveržiai paveldosaugoje, Urbanistika ir architektūra 3(30): 143-158.

Bučas, J. 1995. Urbanistikos paveldo saugotinos teritorijos, Urbanistika ir architektūra 1-2 (19-20): 156-172.

Klaipedos senamiesčio regeneracijos projektas. Detalus išpla navimas. Senamiesčio siluetas ir išklotinès. 1973-1975. Proj. autoriai N. Zubovienè ir V. Zubovas. Klaipedos m. savivaldybės Paminklotvarkos skyriaus archyvas.

Klaipédos senamiesčio regeneracijos projektas. Teritorija tarp Danés upès, Pilies g-vés, laivu statyklos „Baltija“ ir Kuršiu marių. Teritorijos urbanistiniai tyrimai ir regeneravimo pasiūlymai. 1993. 41-5100-02-PD.10-1. Obj. moksl. vadovas V. Šliogeris. Klaipèdos m. savivaldybès Paminklotvarkos skyriaus archyvas.

Klaipèdos senamiestis. Teritorija tarp Danès upès, Kuršių mariu, jūru prekybos uosto ir Uosto gatves. Urbanistiniai tyrimai ir regeneravimo pasiūlymai. 1993. Obj. moksl. vadovas V. Šliogeris. Klaipèdos m. savivaldybès Paminklotvarkos skyriaus archyvas. 
Klaipédos senamiestis. Teritorija tarp Danès upés, uosto, sankryžos, N. Uosto, Dariaus ir Girèno, J. Janonio ir H. Manto gatviu. Urbanistiniai tyrimai ir regeneravimo pasiūlymai. 1994. Proj. autorius L. Šliogerienè. Klaipèdos m. savivaldybès Paminklotvarkos skyriaus archyvas.

Klaipedos miesto aukštybiniu pastatu išdèstymo schema specialusis planas (patvirtintas $2007 \mathrm{~m}$. birželio $28 \mathrm{~d}$. Nr. T2 - 201. Klaipeda). Temos vadovas A. Vyšniūnas, kiti autoriai I. Alistratovaitè, Z. J. Daunora, A. Vyšniūnas.

Miškinis, A.; Bučas, J. 1995. Urbanistikos paveldo saugotinos teritorijos Klaipedos miesto 1945 metu administracinese ribose. Konsultantas: J. Tatoris. Kaunas, II „Kraštotvarka“.

Pakalnis, M. 2000 Miestų užstatymo tankinimo metodikos parinkimas ir Vilniaus Naujamiesčio tankinimo programa, Urbanistika ir architektūra XXIV(4): 149-161.

The Endless City. 2007. The Urban Age Project by the London School of Economics and Deutsche Bank's Alfred Herrhausen Society. UK: Phaidon, 134-161.

Verbakel, E.; Derman, E. 2008. Urban [IM] plants. Tactics for Recombining Landscape and Collective Space in Bonheiden, Belgium, Architectural Design 78(1).

Vilniaus miesto bendrasis planas, operatyvusis planavimas, užstatymo tankinimo galimybiu mieste nustatymas. 2001. Užstatytų Vilniaus teritorijų tankinimo metodika. St „Vilniaus planas“, VP 99-75, VP 2000-32, t. I.

Vilniaus miesto bendrasis planas, operatyvusis planavimas, užstatymo tankinimo galimybiu mieste nustatymas. 2000. Užstatymo tankinimo Vilniaus Naujamiestyje rekomendacijos. SI „Vilniaus planas“, VP 99-75, VP 2000-32, t. I.

Ward, S. V. 2002. Planning the Twentieth-Century City. The advanced capitalist world. UK: John Wiley \& Sons, $16-20$.

Гутнов, А.; Глазычев, В. 1990. Мир архитектуры. Москва: Молодая гвардия.

Маклакова, Т. Г. 2006. Высотные здания. Москва: Издательство Ассоциации строительных вузов (АСВ). $160 \mathrm{c}$.

Кожаева, Л. 1987. Морфотипы застройки центра Москвы, Архитектура СССР 9-10: 102 - 107.

О внесении изменений в МГСН 1.01-99 "нормы и правила проектирования планировки и застройки Москвы на территории морфотипов исторической застройки». Постановление Правительства Москвы от 11 октября 2005 г. № $773-П \Pi$.

\section{POSSIBILITIES AND PROBLEMS IN THE FORMATION OF SEAPORT VISUAL IMAGE: SPECIAL PLAN OF HIGH-RISE BUILDINGS FOR KLAIPE்DA - SPECIFICATION OF SOLUTIONS AND ASSESSMENT OF THEIR IMPACT}

\section{Alistratovaitè}

Abstract. This paper deals with the issue of high-rise building development and problems related to the formation of city development vision in today's Lithuania. The analysis focuses on the possibilities and problems arising in the process of developing the Special Plan of high-rise building arrangement in Klaipeda and in the formation of the visual image of Klaipeda city. The methodology of this Plan is discussed in two papers by the author. The first paper discussed two initial phases of the Plan preparation: the existing status of Klaipeda city and search for a conception of high-rise building arrangement. The present paper touches upon two further preparation phases: specification of solutions and assessment of their impact from various perspectives. City territories are assessed by the following aspects: forecasted development of the morphostructure buildup in the city's structural elements, forecasted development of the perspective background high-rise of the city's structural elements and specification of development of high-rise construction in the urban structure. This paper presents the results of the Special Plan of high-rise building arrangement. It also provides assessment of the impact of the solutions of high-rise building arrangement on the city's visual image as viewed from specified public viewing points as well as the impact on the general development of the city's silhouette and panoramas.

Keywords: Klaipeda, Special Plan, formation of visual image, morphostructure of the city, high-rise buildings, specification of solutions, visual identity.

\section{INESA ALISTRATOVAITÉ}

Doctor of the Humanities (arch.), Assoc Prof, Dept of Urban Design, Vilnius Gediminas Technical University (VGTU), Pylimo g. 26/Traku g. 1, st. 1/26, LT-01132 Vilnius, Lithuania. E-mail: inesa.al@gmail.com

Doctor of the Humanities (arch.) (2005), Master of Architecture (2000), Bachelor of Architecture (1998), VGTU. Teaching: lectures on urban design, urban renewal and computer urban analysis (of GIS base). Publications: author of 7 research papers. Conferences: reports at 12 international and national conferences or seminars. Projects: author or co-author of some special plans, several detailed layouts and building designs. Research interests: spatial layout structure of towns, urban morphology. 